Toplum Bilimleri Dergisi - Journal of SocialSciences

ISSN: 1306-7877 e-ISSN: 2147-5644

15 Kasım / November 2019, 26 : 242-282

\title{
Karikatürlerde Osmanlı Figürünün Göstergebilimsel Analizi: Uykusuz Dergisi Örneği
}

Semiological Analysis of Ottoman Figure in the Caricatures: The Case of Uykusuz Magazine

\section{Zehra ÖĞÜT}

İstanbul Üniversitesi, Sosyal Bilimler Enstitüsü, Din Sosyolojisi, Doktora Öğrencisi, Tübitak Bursiyeri Istanbul University, Institute of Social Sciences, Sociology of Religion, Ph.D. Student, Tubitak Scholar Istanbul, Turkey zehracetin19@gmail.com https://orcid.org/0000-0002-7668-2111

\section{Makale Bilgisi / Article Information}

http://dx.doi.org/10.29228/tbd.2007.39782

Makale Türü / ArticleTypes: Araştırma Makalesi / Research Article

Geliş Tarihi / Received: 2 Eylül / September 2019

Kabul Tarihi / Accepted: 16 Ekim / October 2019

Yayın Tarihi / Published: 15 Kasım / November 2019

Yayın Sezonu / PubDateSeason: Özel Sayı / Special Issue 2019

Cilt / Volume: 26

Sayfa / Pages: 242-282

Copyright @ Published by Toplum Bilimleri Dergisi - Journal of Social Sciences. All rights reserved. www. toplumbilimleri.com 


\section{Karikatürlerde Osmanlı Figürünün Göstergebilimsel Analizi: Uykusuz Dergisi Örneği}

Öz: Kitle kültürünün en önemli gösterenleri olan yazılı ve görsel iletişim araçlarının gelişmesi ile güç kazanan karikatür sanatı, ait olduğu coğrafyanın sanat tarihi yanında düşünce tarihi açısından da önem arz etmektedir. İçinden çıktığı toplumun sosyo-kültürel yapısı ile ciddi bağlantılar taşıyan karikatürler, toplum adına ve toplum üstüne kurulan söylemlerin oluşumu ve muhafazasında da önemli roller icra etmektedir. Bir Batılılaşma hareketi olarak Kemalist devrim ve bu dönemde geride bırakılan/bırakılmaya çalışılan Osmanlıya karşı siyasi sınıf, devlet, aile, milli eğitim, akademi ve medya kanalıyla kurulan söylemlerin bugüne değin bir devamlılık seyri içerisinde muhafaza edildiği/yeniden üretildiği söylenebilir. Bu doğrultuda çalışmada haftalık mizah dergisi Uykusuz, 2015 MayısAğustos ve 2018 Mayıs-Ağustos olmak üzere toplam otuz iki sayı boyunca, "Osmanlı" göstergesi üzerinden taranmıştır. Osmanlı göstergesi, sarık, cübbe, fes, sakal, tespih, takke, şalvar pantolon gösterenlerini kapsamaktadır. Seçilen iki dönemde Osmanlının işlenişi üzerindeki değişiklikleri tespit adına karşılaştırma yapmak hedeflenmiştir. Çalışma ile dinî, İslamî, tarihsel ve geleneksel bir figür olarak Osmanlı göstergesinin, kendisini seküler çizgide konumlandıran bir dergide mizaha nasıl konu edildiği gösterilmek istenmektedir. Osmanlı göstergesi ağırlıklı olarak padişah ve fes gösterenleri ile işlenmektedir. Mutsuzluk ve tedirginlik temaları karikatürlerdeki asıl tema olmakla birlikte, padişahlar bazen otoritesiz bazen baskıcı ve korku salan devlet adamları olarak çizilmişlerdir.

Anahtar Kelimeler: Din Sosyolojisi, Karikatür, Osmanlı, Din, İslam, Kemalizm, Göstergebilim.

Semiological Analysis of Ottoman Figure in the Caricatures: The Case of Uykusuz Magazine

Abstract: The art of caricature which has gained power by the development of written and visual comminication tools- which are most important signifiers of mass culturehas vital importance in terms of history of thought in addition to art history of the geography which it belongs. The caricatures which have strong connections with socio-cultural structure of the society in which it came out, have significant roles in terms of generation and protection of the discourses based on its society. It can be said that the discourses established through Kemalist revolution as a Westernization movement and the political class, state, family, national education, academia and media against the Ottoman Empire which were left behind/tried to be left behind in this period have been maintained/reproduced in a continuum course. In this article weekly humor magazine Uykusuz was scanned through the 
Ottoman sign for a total of thirty-two issues May-August 2015 and May-August 2018. The Ottoman sign includes sarik, gown, fez, beard, prayer-beads, skullcap, baggy trouser. It is aimed to make comparison in order to determine the changes on processing of Ottoman in the two selected periods. The aim of the study to show how Ottoman sign as religious, Islamic, historical and traditional figure is placed on a secular line in a magazine. The Ottoman sign has mainly processed with the sultan and the fez signifiers. Although the themes of unhappiness and uneasiness are the main themes in the caricatures, the sultan has sometimes drawn as statesmen without authority, sometimes repressive and fearful.

Keywords: Sociology of Religion, Caricature, Ottoman, Religion, Islam, Kemalism, Semiology.

\section{GİRIŞ}

Kitle iletişim araçlarının en etkilisi olarak kabul edilebilecek yazılı ve görsel basın yalnız metinler aracılığı ile ideoloji üretmemektedir. Herhangi bir düşüncenin benimsetilmesinde fotoğraf ve çizimin etkisi bazen metnin etkisinin önüne geçmektedir. Karikatürler ise bu bağlamda ayrıca anlamlıdır. Karikatür içerdiği mizah ve okuru yormayan anlatımı ile toplum tarafından talep edilen ve yine toplum üzerinde etkili olan bir sanattır. Çizimlerin anlamlandırılması meselesi ise çizer ve okur aynı ideolojik çizgide olduğunda daha sorunsuz ve kolay olmaktadır. Karikatürün hedeflediği asıl mizah da bu noktada gerçekleşmektedir. Çalışmada Mürekkep Yayıncılık tarafından perşembe günleri çıkarılan haftalık mizah dergisi Uykusuz, 2015 Mayıs-Ağustos ve 2018 Mayıs-Ağustos olmak üzere toplam otuz iki sayı boyunca "Osmanlı" göstergesi üzerinden taranmış, fakat siyasî içerik ve cinsel ifadeler barındıran karikatürler kapsam dişında tutulmuştur. Osmanlı temsili gösterenleri sarık, cübbe, fes, sakal, tespih, takke, şalvar şeklinde tespit edilmiştir.

“Gösterge olmaksızın ideoloji olmaz...İdeolojik olan her şey göstergebilimsel bir değer taşır."1 düşüncesinden hareketle dergideki çizimleri mümkün kılan ideoloji olması bakımından Kemalist ideoloji/Cumhuriyet ideolojisine başvurulacaktır. Kemalizm'in, Batılılaşmayı/modernleşmeyi "telafi edici" ve "tarihsel gecikmişliği giderici" bir araç, belki bir hedef gören karakteri ile Türkiye Cumhuriyeti'nin kurucu ve resmî ideolojisi olduğu bilinmektedir. Bir diğer ifade şekliyle Batılılaşma yolu ile modernleşme resmî ideolojinin ana unsurlarından biridir. Kanaatimizce daha da önemli olan husus bir ideoloji/düşünceler

\footnotetext{
${ }^{1}$ Pelin Önder Erol, "Bir Toplumsal Göstergebilim Alanı Olarak Dil”, Uluslararası Sosyal Araştırmalar Dergisi $7 / 31$ (2014), 212.

2 Ahmet Çiğdem, "Batılılaşma, Modernite ve Modernizasyon”, Modern Türkiye'de Siyasi Düşünce: Modernleşme ve Batıcılık, ed. Tanıl Bora \&Murat Gültekingil (İstanbul: İletişim Yayınları, 2007), 3/68.
} 
sistemi ve bir düzen/eylemler bütünü olarak Kemalizm, geçmiş ve gelecek Türkiye tarihi boyunca tek yeterli ideoloji olarak görülüyor ve görülecek olmasıdır. ${ }^{3}$ Türkiye'ye Batıyı, çağdaşlı̆̆ı, bilimi, sekülerliği getirdiği kabul edilen bu dünya görüşünün, içinde bulunulan coğrafyada modernlik namına atılan her adımda, kurulan her söylemde hâkim paradigma olduğu kabul edilmelidir. Bu minvalde çalışmaya konu olan Uykusuz dergisi Kemalist/modern/seküler çizgide kabul edilmiş ve Osmanlı göstergesinin işlendiği karikatürlerin resmî ideoloji referansı üzerinden okunması gerektiği üzerine tarafımızda kanaat hasıl olmuştur. Cumhuriyet ideolojisinin oluşum yılları olarak kabul edilen 1930'lu yıllarda, inkılâplar ve yeni Türkiye'yi anlatma, tanıtma ve benimsetme adına oluşturulan literatür ise ideolojiye dair temel referans noktası olarak tespit edilmiştir. Din temelli Osmanlı kimliğinden reformist bir şekilde, modern ve laik yeni bir kimlik yaratmaya çalışan resmî ideoloji, ${ }^{4}$ bu yeni kimliğin kabul edilmesi/benimsenmesi noktasında sert politikaların yanında bir kısmına bu çalışmada yer verilecek olan oldukça sert söylemler kurma yoluna da gitmiştir. Söz konusu kaynaklar bu söylemleri içermesi bakımından ayrıca değerli görülmekle birlikte, Kemalist ideolojinin din, İslam, Osmanlı ve tarih meselesini tespit adına da oldukça önemli bir yerde durmaktadır. ${ }^{5} \mathrm{Bu}$ minvalde çalışmanın hipotezi derginin Osmanlıyı karikatürize ediş şekli, Kemalist ideoloji tarafından kurulan söylemlerle uyum arz etmektedir şeklinde belirlenmiştir. Osmanlı temsilinin göstergebilimsel analizinin hedeflendiği bu çalışmada öncelikle Ferdinand de Saussure'ün göstergebilim yaklaşımı ortaya konulacak, ardından karikatürlerdeki ideolojik kodları çözebilme adına Kemalist literatürdeki Osmanlı tasvirleri gösterilecek ve karikatürler bu doğrultuda değerlendirilmeye çalışılacaktır.

\section{GÖSTERGEBİLIM VE SAUSSURE YAKLAŞIMI}

Türkçede özellikle dilbilim (linguistique) sözcügünden mülhem üretilen göstergebilim (semiologie), ilk planda göstergeleri inceleyen bilim dalı olarak tanımlanabilir. Gösterge ise, bir başka şeyin yerini tutabilecek nitelikte olduğundan kendi dışında bir şey gösteren, belirten (anlamı olan) her çeşit biçim, nesne, olgu vb. olarak tanımlanır. ${ }^{6}$ Bir başka ifade şekliyle gösterge, kendisi o şey olmadığı halde, o şeyi çağrıştırarak iletişim sağlayan

\footnotetext{
${ }^{3}$ Taha Parla, “Kemalizm Türk Aydınlanması mı?”, Modern Türkiye’de Siyasi Düşünce: Kemalizm, ed. Tanıl Bora, Murat Gültekingil (İstanbul: İletişim Yayınları, 2009), 2/315.

${ }^{4}$ Fatih Şahbaz, "Kemalizm ve Seküler Fundamentalizm”, Medeniyet Araştırmaları Dergisi 4/1 (2019), 4.

${ }^{5}$ Detaylı bilgi için bk. Zehra Öğüt, İnklâp Kitaplarında Din: 1930’lu Yıllar (İstanbul: Yazıgen Yayınları, 2018). Mevzubahis edilen kaynaklar için bk. Selim Nüzhet Gerçek, "Cumhuriyet'in Onuncu Yıldönümünde Yapılan Neşriyat” Ülkü Halkevleri Mecmuası 2 (1934), 443-455. Ayrıca bk. Nezahat Demirhan, Cumhuriyet'in Onuncu Yılının Türk Inkılâp Tarihinde Yeri ve Önemi (Ankara: Atatürk Kültür, Dil ve Tarih Yüksek Kurumu Yayınları, 1999).

${ }^{6}$ Mehmet Rıfat, Göstergebilimin ABC'si (İstanbul: Simavi Yayınları, 1992), 5.
} 
aracılardır. Nihai olarak semiyoloji yani göstergebilim, aşağıda ele alınmaya çalışılacak olan Saussure'ün dilbilim yönteminin yeni alanlara uygulanmasının sonucudur. ${ }^{7}$

Kültür ve iletişim ise göstergelerin oluşmasında önemli etkenlerdir. Konu bağlamında kültür, her türlü araç, bilgi, düşünce ve toplumsal örgütlenme ve yapılanmaların tümü olarak tanımlanabilir. ${ }^{8}$ Gerek kültürün oluşumu gerekse aktarımı bakımından da iletişim önem arz etmektedir. Dil ise bu noktada devreye girer. İletişimin temel taşıyıcısı olan dil, bir göstergeler dizgesi olarak, göstergebilimin yapı taşını oluşturmaktadır.

Göstergebilimsel analiz metotları ile karikatür çözümlemesinin yapılmaya çalışılacağı Saussure'ün dilbilime dair geliştirmiş olduğu yöntem, bugün yapısalcılık olarak bilinen yaklaşımın temellerinde yer almaktadır. Düşünürün kurmuş olduğu sistemi önemli kılan bir başka husus ise dilbilimden ayrı olarak bir başka bilim dalının fikirsel nüvelerini ortaya atmış olmasıdır:

“Dil, kavramları belirten bir göstergeler dizgesidir. Onun için de, yazısıyla, sağırdilsiz alfabesiyle, kutsal nitelikli simgesel törenlerle, bir toplumda incelik belirtisi sayılan davranış biçimleriyle, askerlerin bildirişim belirtkeleriyle vb. karşılaştırılabilir. Yalnız, dil bu dizgelerin en önemlisidir. Demek ki, göstergelerin toplum içindeki yaşamını inceleyecek bir bilim tasarlanabilir: Toplumsal ruhbilime, bunun sonucu olarak da genel ruh bilime bağlanacak bir bilim. Göstergebilim (Fransızca semiologie, Yunanca semeion "gösterge"den) diye adlandıracağız biz bu bilimi. Göstergebilim, göstergelerin, hangi yasalara bağlı olduğunu öğretecek bize. Henüz yok böyle bir bilim. (...) Ama kurulması gerekli; yeri önceden belli. Dilbilim bu genel nitelikli bilimin bir bölümünden başka bir şey değil. Onun için göstergebilimin bulacağ1 yasalar dilbilime de uygulanabilecek. Böylece insana ilişkin olgular bütünü içinde dilbilim iyice belirlenmiş bir alana bağlanabilecek." ${ }^{9}$

Saussure, burada dili bir göstergeler dizgesi olarak tanımlamakta, göstergebilim olarak isimlendirdiği bir bilim dalının kurulmasının gerekliliği üzerinde durmakta, dilbilimi göstergebilimin, göstergebilimi de ruhbiliminin (psikoloji) bir dalı olarak tasnif etmektedir. Bununla birlikte düşünür, esasında göstergebilimi ruhbiliminden de bir nevi ayırma işlemine

\footnotetext{
${ }^{7}$ Rosalind Coward \& John Ellis, Dil ve Maddecilik, çev. Esen Tarım (İstanbul: İletişim Yayınları, 1985), 50.

${ }^{8}$ Fatma Erkman, Göstergebilime Giriş (İstanbul: Alan Yayıncılık, 1987), 14.

${ }^{9}$ Ferdinand de Saussure, Genel Dilbilim Dersleri, çev. Berke Vardar (Ankara: Türk Dil Kurumu Yayınları, 1976), 1/36-37.
} 
tabi tutmaktadır denilebilir. Ruhbilimin göstergelerin özellikleriyle ilgilenmemesi ve artzamanlı/artsüremli değişimi temel göstergesel olgu olarak ele alamaması sebebiyle göstergebilim, ruhbilimden özerk hale gelmektedir. ${ }^{10}$ Saussure, dilbilimini genel göstergeler biliminin bir bölümü olarak düşünmektedir. Göstergebilimin konularını oluşturan nesneler, görüntüler ve davranışların bağımsız var olmadıkları, her gösterge dizgesinin dil ile karışık bir halde bulunduğu dikkate alınırsa göstergebilimi, dilbilimin bir bölümü olarak okumak daha yerinde bir okuma olsa gerektir. Göstergebilimci, her ne kadar dil dışı unsurlar üzerinde çalışıyor görünse de çalışmalarında yolu dil ile mutlaka kesişecektir. Karşılaşılan bu dil, yalnızca örnekçe olarak değil, bileşen, aracı ya da gösterilen olarak ortaya konulacaktır. Bu şekildeki dil artık bir dilbilimcinin dili değil, söylemlerin büyük parçaları haline gelmiş olan ikinci bir dildir. ${ }^{11}$

Saussure esasında bir dilbilimcidir ve onun göstergebilime katkısı da bu minvalde okunmalıdır. Düşünür teorisini ikili ayrımlar üzerinden kurmaktadır; dil (la langue) ve söz (la parole), onun bu ayrımları içerisinde en belirleyici olanıdır. Ancak dil ve söz kendinden önce dil yetisi ve dil ayrımını gerekli kılmaktadır. Dil, “insanların bildirişmesini, düşündüklerini, duyduklarını başkalarına iletmesini sağlayan yeti"12 olarak tanımlanan dil yetisinin en önemli ve fakat bir bölümünü oluşturmakta ve düşünür tarafından "dil, dil yetisinden söz çıkınca kalan şeydir" şeklinde formüle edilmektedir. ${ }^{13} \mathrm{Bu}$ iki kavram arasında yapılan ayrım, insan dil yetisine sahip olmasa dahi dil denen toplumsal bir varlı̆̆ın var olacağ1 şeklinde bir meali içermektedir. Saussure'ün dil yetisi ve dil ayrımında vurgulamak istediği husus, dilin, dil yetisinin toplumsal bir ürünü olduğu ve daha da önemlisi bu yetinin bireylerce kullanılabilmesi için toplumun benimsediği zorunlu anlaşma ürünü olan kurallar bütünü olduğudur. Bununla birlikte altı çizilmesi gereken husus, dil kendi başına bir bütün ve bir sınıflama ilkesidir. ${ }^{14}$ Dil yetisi içerisinde dilin konumunu gösterebilme adına düşünür ayrıca bir söz çevriminin işleyişini şematize etmektedir. Bu şemaya göre iki temel öğe bulunmaktadır: Kavram ve işitim imgesi. Kavramlar bilinç olgularını dile getirirken, işitim imgesi bu kavramın seslendirilmesidir. Düşünür çalışmasında "ağaç" kavramını kullanmaktadır. Buna göre "ağaç" kavramı sesleme yoluyla diğer kişiye iletilmekte ve kavramı duyan kişi aynı işitim imgesini zihninde kavrama çevirerek anlam iletme ve anlama sürecini tamamlamış olmaktadır. ${ }^{15}$

\footnotetext{
${ }^{10}$ Saussure, Genel Dilbilim Dersleri, çev. Berke Vardar, 1/6-38.

${ }^{11}$ Roland Barthes, Göstergebilimsel Serüven, çev. Mehmet Rıfat \& Sema Rıfat (İstanbul: Kaf Yayıncılık, 1985), 32-33.

${ }^{12}$ Adnan Onart, "Değişik Yönleriyle Yapısalcılık ve "Yapı” Kavramı”, Türk Dili Dergisi 262 (1973), 239.

${ }^{13}$ Saussure, Genel Dilbilim Dersleri, çev. Berke Vardar, 1/71. Ayrica bk. Roland Barthes, Göstergebilimsel Serüven, çev. Mehmet Rıfat \& Sema Rifat, 35.

${ }^{14}$ Saussure, Genel Dilbilim Dersleri, çev. Berke Vardar, 1/31.

${ }^{15}$ Saussure, Genel Dilbilim Dersleri, çev. Berke Vardar, 1/32-33, 60-61.
} 
Dili, dil yetisinin toplumsal yönü olarak tanımlayan Saussure, dil yetisinin bireysel yönüne de işaret etmekte ve o bilinen dil-söz ayrımına yer vermektedir. Daha evvel de işaret edildiği üzere dil ve söz ayrımı Saussure düşüncesinde oldukça önemsenen bir ayrımdır. Düşünür bunu bir kâğıdın iki yüzü benzetmesi ile izah etmeye çalışır. Bu iki unsur farklı alanlara yönelseler de kökenleri aynı noktadadır. Düşünüre göre dil ve sözü birbirinden ayırmak demek "toplumsal olguyu bireysel olgudan, önemli olguyu önemsiz, belli oranda rastlantısal nitelik taşıyan olgudan ayırmak" demektir. Dil, konuşan kişinin işlevi değildir, bireyin edilgen biçimde belleğine aktardığı bir üründür. Buna mukabil söz kişinin bireysel bir istenci ve anlık (bilinç) eylemidir. Bu eylemde de iki hususa dikkat çekilmekte, konuşan bireyin, kişisel düşüncesini anlatmak için dil dizgesini kullanmasını sağlayan birleşimlerin ve bu birleşimleri dışa iletmesini sağlayan anlıksal (bilinçsel)-fiziksel düzeneğin birbirinden ayırt edilmesi gerektiği belirtilmektedir. ${ }^{16}$ Saussure'ün önemli olgunun önemsiz olgudan ayrılması şeklinde yer verdiği husus, esasında, dilin bir dizge oluşuna işaret etmektedir. Yapısalcılığın başlangıç noktası olarak kabul edilen düşünürün eserinde "yapı" sözcüğü geçmemekte, bunun yerini doldurur tarzda "dizge" sözcüğüne yer verilmektedir. Ona göre dil, içerisindeki öğelerin arasında karşılıklı bağıntıların olduğu bir dizgedir. Dilsel öğeler arasındaki ayrılık ve karşıtlık bağıntılarının oluşturduğu kurallılık ve yasallık da bir düzen ve dizge oluşturmaktadır. ${ }^{17}$ Dilin birtakım öğelerin yalnızca bir toplamı ve bir yığınından daha fazla bir şey olduğuna yönelik vurguyu içeren "dizge" kavramı, temelde, dilin bir göstergeler dizgesi olduğunu ifade etmeye yöneliktir. Bu noktada evvela söylenmesi gereken, Saussure düşüncesinde dilsel göstergelerin doğrudan nesnelerle değil, zihinsel kavramlarla ilişkili olduklarıdır.

Dil ve söz ayrımını söz konusu düşüncede önemli kılan, dil ve söz alanında göstergelerin kullanılmasıdır. Gösterge, gösteren ve gösterilen Saussure düşüncesinde bir diğer uğrak noktası ve hatta göstergebilim açısından en temel olanıdır. "Nasıl satranç oyunu tümüyle çeşitli taşların birleşiminden başka bir şey değilse, dil de baştan aşağı somut birimlerinin karşıtlığına dayanan bir dizgeden başka bir şey değildir. Ne bu birimleri tanımaktan kaçınabilir ne de onlara başvurmadan bir adım bile atabiliriz."18 Bir göstergeler dizgesi olan dilde de dikkate alınması gereken temel unsurları Saussure, gösteren, gösterilen ve gösterge olarak tespit etmektedir. Barthes, Saussure'ün bu terimleri bir süre aradığını ve düşünürün "biçim-düşünce" ve "imge-kavram” gibi kavramları değerlendirdikten sonra göstergeyi oluşturan gösteren ve gösterilende karar kıldığını ifade etmektedir. ${ }^{19}$ Saussure

\footnotetext{
${ }^{16}$ Saussure, Genel Dilbilim Dersleri, çev. Berke Vardar, 1/34-35.

17 Onart, "Değişik Yönleriyle Yapısalcılık ve "Yapı" Kavramı”, 238.

${ }^{18}$ Saussure, Genel Dilbilim Dersleri, çev. Berke Vardar, 1/44.

${ }^{19}$ Roland Barthes, Elements of Semiology, çev. Annette Lavers \& Colin Smith (New York: Hill and Wang Press, 1977), 35 .
} 
düşüncesinde yer alan "dil göstergesinin bir nesne ile bir adı birleştirmediği, bir kavramla bir işitim imgesini birleştirdiği" ve "dil göstergesinin kapsadığı her iki öğenin de anlıksal nitelikli oluşu ve bunların beynimizde çağrışım yoluyla belirlendiği ${ }^{20}$ şeklindeki iki ilke göstergenin bileşenleri arasındaki ilişkiyi anlama adına oldukça önemlidir. Düşünürün bir söz çevriminde işitim imgesi ve kavram olarak göstermiş olduğu iki unsurdan, göstergeye dair çizilen şemada, işitim imgesi "gösteren"e, kavram ise "gösterilen"e denk düşmektedir. Saussure bu durumu "bütünü belirtmek için gösterge sözcüğü kullanılmalı, kavram yerine gösterilen ve işitim imgesi yerine de gösteren benimsenmelidir" ${ }^{21}$ şeklinde ifade etmektedir. Dilsel kendiliğin varlığını yalnızca gösterenle gösterilenin bileşimine borçlu olduğunu belirten düşünür, aradaki ilişkiyi de çağrışım ilişkisi şeklinde tespit etmektedir. Göstergenin bileşenlerinden biri olan gösterilen, nesnenin zihinsel bir tasarımı ve göstergeyi kullanan kişinin anladığ şey iken, gösteren, gösterileni imleyen her türlü öğedir. Gösteren ve gösterilen arasındaki ilişki, yani anlamlandırma süreci ise en temelde "kültürel bir buyrukla"22 meydana gelmektedir.

Saussure gösteren ve gösterilen arasında iki temel ilişki kurmaktadır. Bunlardan biri "göstergenin nedensizliği" ilkesidir ki göstereni, gösterilene birleştiren bağın nedensiz olduğu anlamına gelmektedir. Bununla, söz gelimi "kardeş" kavramının, kendisine gösterenlik yapan "k-a-r-d-e-ş" ses dizisiyle hiçbir iç bağıntısının olmadığı kastedilmektedir. Bir toplumun benimsediği bütün anlatım biçimlerinin ki bunlar içerisinde belli bir doğal anlatımlılıkla yüklü toplumsal incelik göstergeleri de dahil, ilkece toplumsal bir alışkanlığa ya da toplumsal bir sözleşmeye dayalıdır. Bu noktada Saussure'ün iki türlü göstergeyi birbirinden ayırt ettiği, gökyüzüne yükselen dumanın, bir yerlerde yakılmış ateşin göstergesi olmasına benzer durumları ifade etmek üzere "doğal gösterge" tabirini kullandığı ve buradaki gösterge bileşenleri arasındaki ilişkiyi nedensellik olarak tespit ettiğini belirtmek gerekir. Buna mukabil dilsel göstergelerde gösterge bileşenleri arasında hiçbir doğal bağlantı bulunmamakta ve bu haliyle göstergelerin her bakımdan nedensiz olanlarının göstergesel yöntemin ülküsünü diğerlerinden daha iyi gerçekleştirdiği belirtilmektedir. Anlatım dizgelerinin en karmaşığı olarak tavsif edilen dil ve dilbilim, düşünüre göre, her türlü göstergebilimin genel örneği olabilecektir. ${ }^{23}$ Nedensizlik ilkesine dair kaydedilmesi gereken bir başka husus, bu ilkenin, konuşan bir kimsenin göstereni istediği gibi özgürce seçebileceği anlamına gelmemesidir. Çünkü dilin toplumsal bir sözleşme olması işitim imgelerinin değişmez görsel imgelere dönüştürülebilmesi sayesinde gerçekleşir. Yine Saussure'e göre

\footnotetext{
${ }^{20}$ Saussure, Genel Dilbilim Dersleri, çev. Berke Vardar, 1/60.

${ }^{21}$ Saussure, Genel Dilbilim Dersleri, çev. Berke Vardar, 1/61.

${ }^{22}$ Mark Gottdiener, Postmodern Göstergeler, Maddi Kültür ve Postmodern Yaşam Biçimleri, çev. Erdal Cengiz, Hakan Gür, Arhan Nur (Ankara: İmge Kitabevi Yayınları, 2005), 17.

${ }^{23}$ Saussure, Genel Dilbilim Dersleri, çev. Berke Vardar, 1/62.
} 
dilsel bir gösterge bir toplulukta yerleşti mi onda herhangi bir değişiklik yapmak bireyin elinde değildir. ${ }^{24}$ Düşünür bununla göstergelerin değişmeyeceğini kastetmemektedir. Göstergeler, diğer göstergelerle olan ilişkileri ve uzlaşma sürecine göre değişebilirler. Saussure göstergenin değişmezliğini ve değişebilirliğini birlikte değerlendirmektedir.

Dilsel göstergelerin nedensizliği/keyfiliği ilk planda göstergenin değişmezliği ilkesine atıfta bulunmaktadır. Gösteren, belirttiği kavram açısından özgür bir seçim ürünü olmakla birlikte, kendisini kullanan dilsel topluluk bakımından özgür değil, zorunlu bir seçimdir. Topluma bir şey sorulmadığı gibi dilin seçtiği gösteren yerine de bir başkası kullanılamaz. Bireyin rolü ise oldukça pasiftir, birey istese de yapılan seçimi hiçbir yönden değiştiremez. Bu minvalde Saussure dili “eski kuşakların aktardığı ve olduğu gibi benimsenmesi gereken bir ürün" olarak tanımlamaktadır. Dilin kökenine dair tartışmaların yersiz olduğunu belirten düşünür belli bir dil durumunun her zaman tarihsel etkenlerin ürünü olduğunun altını çizmekte, göstergenin niçin değişmez olduğu, bir başka ifadeyle rastgele değiştirime nasıl karşı koyduğunun en temel açıklayıcısının da bu esas olduğunu kaydetmektedir. ${ }^{25}$ Saussure göstergelerin değişmezliği ilkesini, herhangi bir dilin gerektirdiği göstergelerin çokluğu, dil dizgesinin oldukça karmaşık bir düzenek oluşu, dilin konuşulurken mantıksal düşüncenin devreye girmediği, bireylerin büyük ölçüde dil yasalarının bilincinde olmadığı, dilin her an herkes tarafından etki altında bulunmakla birlikte toplumun durgun ve tutucu karakteri gibi tespitlerle izah etmektedir. Ardından meseleyi özetlemesi bakımından önemli görülen ve kaynaklarda da kendisine sıkça atıfta bulunulan şu ifadelere yer vermektedir:

“Ne var ki dilin özgür olmadığını açıklıkla ortaya koyabilmek için toplumsal güçlerin ürünü olduğunu söylemek yetmez; her zaman bir önceki dönemden aktarılmış bir kalıt olduğunu anımsayarak bu toplumsal güçlerin zaman içerisinde etki gösterdiğini de eklemek gerekir. Dilin değişmezliği yalnız toplumun ağırlığından ileri gelmez; zaman içinde yer alışının da ürünüdür. Bu iki olgu birbirinden ayrılamaz. Her an geçmişe bağl1lık seçme özgürlüğünü köstekler. İnsan diyoruz, köpek diyoruz neden? Bizden öncekiler öyle demiş de ondan. (...) Seçimi özgür kılan nedensiz anlaşma ve seçimi değişmez kılan zaman. Gösterge nedensiz olduğu için gelenek dışında yasa tanımaz ve ancak geleneğe dayandığ 1 için de nedensiz olabilir." 26

\footnotetext{
${ }^{24}$ Saussure, Genel Dilbilim Dersleri, çev. Berke Vardar, 1/63.

${ }^{25}$ Saussure, Genel Dilbilim Dersleri, çev. Berke Vardar, 1/66.

${ }^{26}$ Saussure, Genel Dilbilim Dersleri, çev. Berke Vardar, 1/68.
} 
Daha evvel yer verildiği üzere Saussure göstergenin değişmezliği ile değişebilirliğini aynı anda savunmaktadır. Dilin sürekliliğini sağlayan zaman, değişmezlik ilkesinin en temel delili olmakla birlikte aynı zamanda da dil göstergelerini değişime uğratmaktadır. Bu Saussure tarafından "bir bakıma göstergenin değişmez olduğu da söylenebilir, değişebilir olduğu da" şeklinde ilkeleştirilmektedir. Bu durum ilk planda bir paradoks gibi görünse de Berke Vardar'ın “Dil değişir, ancak onu bireyler değiştiremez. Dilin dokunulmaz olduğu, ama bozulmaz olmadığı" ${ }^{27}$ şeklindeki şerhi konuya açıklık getiriyor olsa gerektir. Düşünüre göre gösterge bozulma eğilimindedir, çünkü kuşaktan kuşağa aktarılmaktadır. Ancak her bozulmada eski gereç yerinde kalır ve geçmişten kopuş görecedir. Bu sebeple Saussure bozulma ilkesini süreklilik ilkesine dayandırmaktadır. Göstergenin değişebilirliği ile ilgili bir diğer önemli husus da bozulma etkenleri ne olursa olsun, bunlar ister tek tek ister topluca ortaya çısınlar, her zaman gösterilenle gösteren arasındaki bağıntının değişmesi sonucunu verirler. Saussure düşüncesinde hem gösteren hem de gösterilenin salt bağıntısal ya da ayrımsal kendilikler ve nedensiz olduklarından bağıntısal bir ilişki içinde bulundukları bir kez daha hatırlanmalıdır. Gösteren ve gösterilen arasındaki bu bağıntıyı her an değiştirebilecek etkenlere karşı da dil tamamen savunmasızdır ve bu durum da yine göstergenin nedensizliğinin sonuçlarındandır. ${ }^{28}$

Göstergenin nedensizliği ilkesinin bir sonucu olarak Saussure, dil dizgesinin eşsüremli ve artsüremli inceleme yöntemini ele almaktadır. Düşünürün dili, "bütün öğeleri dayanışık, birinin değeri yalnızca öbürlerinin de süremdeş varlığından doğan bir dizge" şeklinde tanımlamasında da görülebileceği gibi eşsüremli dil incelemesi dil dizgesinin zaman göz önüne alınmadan belli bir durumda incelenmesi anlamina gelmektedir. Artsüremli dil incelemesi ise dilin zaman içerisindeki evriminin incelenmesi olarak tanımlanabilir. Eşsüremli ve artsüremli dil incelemeleri göstergenin nedensizliği ilkesi ile birlikte Saussure düşüncesinde dilin değişebilirliği ilkesinin bir sonucu olarak da okunabilir. Gösteren ile gösterilen arasında zorunlu hiçbir bağın olmaması, göstergenin zamandan etkilenmeyecek temel bir çekirdeğinin olmadığı anlamına gelirken, aradaki nedensizlik ilişkisi ile de gösterge tümüyle tarihe bağımlı ve tarihin etkisi altındadır. Göstergenin tarihe bağımlı bu durumu Saussure'e göre göstergelerin tarih dışı çözümlemesini yani eşsüremli betimlemeyi zorunlu kılmaktadır. Bir göstergenin anlamının diğer göstergelerle olan ilişkisiyle belirlenmesi bu durumun başka bir ifadesidir. Mevzubahis düşüncede eşsüremli incelemenin artsüremli incelemeye önceliği temel bir ilkedir. Eşsüremli inceleme dil (la langue) ile ilgiliyken artsüremli inceleme söz (la parole) ile ilgilidir. Ayrıca belirtilmesi gereken husus artsüremli incelemenin eşsüremli incelemeden doğduğu ve dilin tarihsel

\footnotetext{
${ }^{27}$ Berke Vardar, Genel Dilbilim Dersleri (İstanbul: Multilungual Yayınları, 1998), 120.

${ }^{28}$ Saussure, Genel Dilbilim Dersleri, çev. Berke Vardar, 1/69.
} 
evrimi bilinmeden de bir dil konuşulabilecektir. Çünkü dil Saussure'e göre “öğelerinin bir anlık durumu dışında hiçbir şeyin belirlemediği katışıksız bir değerler dizgesi"dir.

Saussure düşüncesinde tarihsel değişiklik, dil dizgesi dışından kaynaklanmaktadır ve artsüremli yaklaşım ve eşsüremli yaklaşım olguları birbirinden farklıdır. Değişim la langue yani dilden değil, dilin edimsel yanı olan la parole'dan yani sözden kaynaklanmaktadır. Değişiklik ise dizgede değil, dizgenin tek tek öğelerinde gerçekleşmektedir. Nihayetinde dizge de bu tarihsel değişimin sonuçlarından yararlanır/etkilenir, ancak bu değişimi üreten dil dizgesi değildir. Burada kaydedilmesi gereken husus Saussure'ün eşsüremli ve artsüremli inceleme arasında yaptığı ısrarlı ayrımın yalnızca ses değişmeleri ile ilgilenmesi ve kendi başına anlam değişmeleri sorunuyla ve gösterilenlerin artsüremli değişmeleri ile ilgilenmemesidir. ${ }^{29}$ Saussure'ün kurduğu bu kuramın gösterilenlerin uğramış olduğu anlam değişimini takibi mümkün kıldığ1 açıktır ve düşünürün dilbilimin diğer göstergebilim alanlarına örnek teşkil edeceğine dair ifadeleri de bunu mümkün kılan en açık ifade olsa gerektir.

Saussure düşüncesinde gösteren ve gösterilen arasındaki iki temel ilişkiden ikincisi gösterenin çizgiselliğidir. Bu ilke gösterenin işitimsel nitelikli olması üzerinden ele alınmaktadır. Düşünür söz konusu ilkeyi "gösteren bir yayılım gösterir ve bu yayılım tek boyutta ölçülebilir, o da bir çizgidir" şeklinde ifade etmektedir. Gösterenin çizgiselliği ilkesi, dilin ses olmaksızın düşünülememesi ile de ilgilidir. Nitekim düşünür dili bir kâğgda benzetmekte, düşünce kâğıdın ön yüzünü, ses ise arka yüzünü temsil etmektedir. Kâğıdın bir yüzü kesildiğinde otomatik olarak diğer yüzü de kesilmiş olacaktır. Dilde de durum aynıdır diyen Saussure, ses ve düşüncenin birbirinden ayrılamaz olduğunun altını çizmektedir. ${ }^{30}$ Dilin tüm düzeneğinin çizgiselliğine bağlandığı bu düşüncede dil öğeleri arasındaki bağıntılar, dizimsel (sentegmatik) ve çağrışımsal (paradigmatik) olarak ikiye ayrılmaktadır. Dil öğeleri arasındaki bağıntı ve ayrılıklar her biri belli bir değerler düzeni yaratan değişik iki alanda ortaya çıkmaktadır. İlk alanda sözcükler, konuşma ya da söylemde birbirlerine bağlanmalarından veya zincirlenmelerinden ötürü dilin çizgiselliğine dayalı bağıntılar kurarlar. Çizgisellik iki öğeyi birden söylememizi imkânsız kılar ve bu öğeler söz zincirinde birbiri ardına sıralanır. Dayanağı uzam olan bu birleşimleri Saussure dizim olarak adlandırır. Birbirini izleyen iki ya da daha çok sayıda birimden oluşan dizim, “ön-görmek ve hava iyi olursa dışarı çıkacağız” şeklinde örneklendirilebilir. Bir dizimdeki öğe değerini kendinden önce veya sonra veya hem önce hem sonra gelen öğelerle olan karşıtlığından almaktadır. Çağrışımsal bağıntı ise aralarında ortak bir yön bulunan sözcüklerin konuşma dışında çağrışım yoluyla bellekte birbirine bağlanması ile

\footnotetext{
${ }^{29}$ Jonathan Culler, Saussure, çev. Nihal Akbulut (İstanbul: Afa Yayınları, 1985), 37-46.

${ }^{30}$ Saussure, Genel Dilbilim Dersleri, çev. Berke Vardar, 1/105.
} 
oluşmaktadır. Bu iki bağıntı şu şekilde toparlanabilir: “Dizimsel bağıntı aynı anda birlikte bulunan öğeler arasındaki bağıntıdır ve gerçek bir dizide yer alan iki ya da daha çok sayıda öğeye dayanır. Buna karşın çağrışımsal bağıntı aynı anda birlikte bulunmayan öğeleri gücül bir belleksel dizide birbirine bağlar." 31

Saussure düşüncesinde değinilmesi gereken bir diğer husus da dilsel değer mevzuudur. Dil salt bir değerler dizgesinden başka bir şey değildir ve kavramlar ve sesler bunun en açık ispatıdır. Buna göre dilsel öğe, "bir kavramın bir sesle birleştiği ve bir sesin bir kavramın göstergesi durumuna girdiği küçük bir üye, bir eklem" olarak tanımlanmaktadır. İlk olarak izaha kavuşturulması gereken husus dil ve düşünce arasındaki ilişkidir: “Dilin düşünceye karşı üstlendiği görev, kavramların anlatımı için özdeksel bir ses aracı yaratmak değil, düşünceyle sese aracılık yapmaktır. Bu o türlü koşullarda gerçekleşir ki düşünceyle sesin birleşmesi zorunlu olarak karşılıklı birim sınırlandırmaları sonucunu verir. Özü gereği bulanık olan düşünce ayrışma yoluyla belirginleşmeye zorlanır. Demek ki ne düşünceler özdekleşir, ne de sesler tinselleşir. Düşünce-ses birtakım bölümlemeler gerektirir ve dil, biçimlenmemiş iki yığın arasında oluşurken kendi birimlerini yaratır." 32 Vurgulanmak istenen husus, daha evvel de geçtiği üzere ne düşüncenin sesten ayrılabileceği ne de sesin düşünceden ayrılabileceğidir. Bu ikisinin birbirinden ayrılması demek Saussure'e göre ya salt ruhbilim ya da salt sesbilim alanında kalınması anlamına gelmektedir ve dilbilim tam da bu iki alanın birleştiği sınır bölgesinde yer almaktadır. Bu konumlanış ise en temelde bir töz değil, bir biçim yaratmaktadır. Bir ses dilimini bir kavrama bağlayan seçme eylemi tam anlamıla nedensizdir ve bu nedensizliğin "değer" kavramını yarattığı söylenebilir. Kavramla ses arasındaki bağın nedensiz oluşu ile değerler baştan başa görece nitelikte kalmaktadırlar.

Göstergelerin nedensizliği ve ancak toplumsal olgunun bir dil dizgesi yaratabilecek olması bu noktada bir kez daha açığa çıkmaktadır ve bir değerler dizgesi olarak dilin değerini yaratanın toplumsal kullanım ve genel onay olduğu tekrar ifade edilmektedir. Saussure düşüncesinde sözcüğün içeriği ancak başka sözcüklerin yardımıyla gerçekten belirlenebilir. Bir dizgenin parçasıdır sözcük, onun için yalnızca bir anlam içermekle kalmaz bir de değer taşır. ${ }^{33}$ Kavramsal yönü bakımından dilsel değer "anlam" ile yakın ilişkilidir ancak mevzubahis düşüncede dilsel değerlerin her dil dizgesinde değiştiği ve önceden belirlenmiş kavramlar yerine dizgeden doğan değerler ile karşı karşıya olunduğu da burada kaydedilmelidir. Bir başka ifadeyle, anlam işitim imgesinin doğal bir karşılığından, bir karşı öğesinden başka bir şey değildir ve her şey, kendi dışında varlık nedeni bulunmayan bir

\footnotetext{
${ }^{31}$ Saussure, Genel Dilbilim Dersleri, çev. Berke Vardar, 1/115-116.

32 Saussure, Genel Dilbilim Dersleri, çev. Berke Vardar, 1/105.

${ }^{33}$ Saussure, Genel Dilbilim Dersleri, çev. Berke Vardar, 1/108.
} 
alan gibi ele alınan sözcügün sınırları içinde, işitim imgesi/gösteren ve kavram/gösterilen arasında gerçekleşir. Buraya Saussure "ama sorunun aykırı görünüşlü bir yönü var: Bir yandan kavram bize işitim imgesinin gösterge içindeki karşı öğesi gibi görünür, bir yandan da bu göstergenin kendisi, bir başka deyişle, onun iki öğesini birbirine bağlayan ilişki dildeki öbür göstergelerin aynı oranda karşı öğesi ya da doğal karşılığıdır." şeklinde bir izah getirir ve bunun üzerinden dili "bütün öğeleri dayanışık, birinin değeri yalnızca öbürlerinin de zamandaş varlığından doğan bir dizge" olarak tanımlar. ${ }^{34}$

Değerin kavramsal bölümü dildeki diğer öğelerle kurulan bağıntı ve ayrılıklarla belirlendiği gibi, özdeksel bakımdan değer için de aynı şey söz konusudur. Sözcüğü ayrıcalıklı kılan sesin kendisi değil, ses ayrılıklarıdır. Saussure'e göre bir dil öğesi nihai olarak, kendi dışındaki öğelerle rastlaşmaması dışında hiçbir temele dayanamayacaktır ve bu durum "nedensiz ve ayrımsal" şeklinde bağlılaşık iki nitelik olarak ifade edilmektedir. Düşünür "dilde yalnız ayrılıklar vardır" ilkesini esasında tüm kuramının temeline yerleştirmektedir. Yalnız bu ayrılık, gösteren ve gösterilen gibi görece öğeler değil, gösterge gibi salt nitelikli bir öğe gerektirmektedir. Bir başka ifadeyle ayrılıklar, salt nitelikli göstergeler arasında ortaya çıkmaktadır denilebilir. Dili bir göstergeler dizgesi olarak tanımlayan Saussure, bir dil dizgesini, bir dizi kavram ayrılığıyla birleşmiş bir dizi ses ayrılığı olarak tespit etmekte, belli sayıdaki işitim göstergesinin, düşünce yığınında yapılmış aynı sayıda bölümlemeyle karşılaşmasından da bir değerler dizgesi doğduğunu ifade etmektedir. Her göstergenin ses ve anlık öğeleri arasındaki gerçek bağı kuran da bu dizgedir. Kendi bünyesinde bir gösteren ve gösterilen barındıran her gösterge birbirinden "ayrık"tır ve aralarındaki bağıntı "karşıtlık" bağıntısıdır. Düşünüre göre tüm dilsel düzenek bu türlü karşıtlıklar ile bunların kapsadığı ses ve kavram ayrılıklarına dayanmaktadır. ${ }^{35}$

Çalışmanın ilerleyen bölümünde Saussure'ün, göstergebilimin de temelinde bulunan, dilbilime dair geliştirmiş olduğu yaklaşımı ile Uykusuz dergisi karikatürlerindeki Osmanlı göstergesi üzerine odaklanılacaktır. Yukarıda ana hatlarıyla verilmeye çalışılan teori, karikatürleri yorumlamayı mümkün kılan üç noktada şu şekilde özetlenebilir:

- Saussure düşüncesinin en temelinde, dil yetisinin toplumsal yönü olarak dil (la langue) ve bireysel yönü olarak söz (la parole) ayrımı bulunmaktadır. Düşünür bu ayrımı en temelde konuşan kişinin kişisel düşüncesini anlatmak için dil dizgesini kullanmasını sağlayan birleşimlerin ve bu birleşimleri dışa iletmesini sağlayan anlıksal-fiziksel düzeneğin birbirinden ayırt edilmesinin gerekliliğini tespit adına yapmaktadır. Buradan varılmak istenen asıl önemli nokta ise,

\footnotetext{
${ }^{34}$ Saussure, Genel Dilbilim Dersleri, çev. Berke Vardar, 1/106-107.

${ }^{35}$ Saussure, Genel Dilbilim Dersleri, çev. Berke Vardar, 1/110- 113.
} 
mevzubahis düşüncede dilsel göstergelerin doğrudan nesnelerle değil, zihinsel kavramlarla ilişkili olduğudur. Bir başka ifade şekliyle dilsel gösterge bir nesne ile bir adı değil, bir kavramla (gösterilen) bir işitim imgesini (gösteren) birleştirmektedir. Diğer önemli husus ise göstergenin bileşenleri olarak gösteren ve gösterilen anlıksal niteliklidir ve beynimizde bunlar çağrışım yoluyla belirlenmektedir. $\mathrm{Bu}$ iki husus doğrultusunda denilebilir ki Osmanlı göstergesinde gösteren olarak tespit edilen sarık, cübbe, fes, sakal, tespih, takke, şalvar pantolon, direk somut bir nesneye değil, muhatabın zihnindeki tasarıma işaret etmektedir. Bu noktadaki anlamlandırma aşamasında ise içerisinde bulunulan kültürel çevre büyük önem arz etmektedir.

- Gösteren ve gösterilen arasında hiçbir içsel bağıntı bulunmamaktadır ve bu "nedensizlik ilkesi" olarak isimlendirilmektedir. Saussure bir toplumun sahip olduğu bütün anlatım biçimlerinin toplumsal bir alışkanlık veya toplumsal bir sözleşmeye dayandığını kabul etmektedir. Nedensizlik ilkesinin işaret ettiği önemli husus "göstergelerin değişip değişemeyeceği" mevzudur. Esasında ikisini de aynı anda savunan düşünür nihayetinde, kuşaktan kuşağa aktarılmaları gerekçesiyle göstergelerin bozulma eğiliminde olduğunu kabul etmektedir. Gösteren ve gösterilen arasındaki bağıntının değişmesi olarak tanımlanabilecek olan bozulmaya karşı dil, nedensizlik ilkesinin sonucu olarak savunmasızdır ve dilsel göstergedeki değişim, nihayetinde dil dizgesini etkilese de dil (langue) dışında, sözde (la parole) gerçekleşmektedir. Saussure bu sebeple dil (la langue) alanında gerçekleşen eşsüremli incelemenin dilbilim hususundaki önemine işaret etmekte, söz (la parole) alanında gerçekleşen artsüremli incelemeye öncelemekte ve gösterilenlerin artsüremli değişimleri ile ilgilenmemektedir. Burada kaydedilmesi gereken husus kanaatimizce, göstergebilim söz konusu olduğunda artsüremli incelemenin de aynı derecede önemli olacağıdır. Osmanlı göstergesi özelinde konuşulacak olunursa, çalışmada gösteren olarak tespit edilen unsurların Osmanlı ile birlikte, din, İslam, tarih, İslam tarihi ve gelenek gösterilenlerine işaret etmesi ve bu unsurların toplumun bir kesimince mizah olarak değerlendirilmekle birlikte, diğer kesiminde rahatsızlık uyandırması belli bir tarih dilimine işaret etmekte ve artsüremli bir incelemeyi gerekli kılmaktadır. Çalışmanın ilerleyen bölümünde görüleceği üzere, değişimin takip edilebileceği tarih dilimi olarak 1930'lu yıllara işaret edilmektedir.

- Saussure gösteren ve gösterilen arasında kurduğu "gösterenin çizgiselliği" ilkesi doğrultusunda dil öğeleri arasında dizimsel (sentegmatik) ve çağrışımsal (paradigmatik) şeklinde iki bağıntı tespit etmektedir. Burada özellikle çağrışımsal 
bağıntı, Osmanlı göstergesini gerek tespit gerek analizi noktasında önem arz etmektedir. Buna göre çalışmada gösteren olarak tespit edilen nesneler, muhatabının zihninde birbirini çağrıştırmaktadır. Diğer bir ifade şekliyle fes denildiğinde sarık, cübbe, tespih vd. kişinin zihninde kendiliğinden canlanmaktadır. Osmanlı göstergesinin bileşenlerinin çalışmada kuruluşşsekli ve boyutları Saussure'ün "yapay dil" terimiyle de izah edilebilir. Ona göre göstergelerin nedensizliği ilkesi kuramsal bakımdan sesle kavram arasında herhangi bir bağıntı kurabilme özgürlüğüne imkân sağlamaktadır. Bu sebeple dil bazen sesleri bazen de anlamları ilgilendiren tüm olguların etkisinde kalarak bozulur, evrim geçirir. Düşünüre göre bu ilkenin doğrulanabileceği alanlardan biri "yapay dil" mevzudur. Yapay dil bir süre kendisini oluşturanın egemenliği altındadır, ancak yaygınlık kazanıp da bildirişim aracı haline geldiğinde geri dönülemeyecek bir hal alır. ${ }^{36} \mathrm{Bu}$ noktada, ilerleyen bölümlerde yer verileceği üzere, özellikle Osmanlı hususunda yapay bir dil oluşturan Kemalist literatürden bahsedilebilir. Bu dil belirli bir tarihsel süreçle birlikte yaygınlık kazanmış ve bildirişim aracı olmuştur. Osmanlı göstergesinin içerdiği anlam bu yol ile oluşturulmuş, Türkiye toplumunda, büyük oranda kabul edilmiştir.

\section{GÖSTERGE, ANLAMLANDIRMA VE IDEOLOJİ}

“Nerede bir gösterge varsa orada ideoloji de vardır." ${ }^{37}$ Voloşinov'a ait bu cümle, Oktay'ın "popüler kültür, yaşamın her anında olumsuz anlamıyla ideoloji üretmekte ve bu ideolojik içeriği kitlelerin bilinç altına yerleştirmektedir." 38 ifadeleri ile açılabilir. Göstergelerin ideoloji üretmedeki rolü Fiske tarafından şu şekilde izah edilmektedir:

“Göstergeler mitlere ve değerlere somut bir biçim verirler ve böyle yaparak onları desteklerler ve kamusal hale getirirler. Biz göstergeleri kullanarak ideolojiye can veririz ve onu yaşatırız, ancak aynı zamanda bu ideoloji ve ideolojik göstergelere verdiğimiz yanıtlar tarafından inşa ediliriz. Göstergeler mitleri ve değerleri kamusal hale getirdiklerinde, onların kültürel özdeşleştirme işlevlerini yerine getirmelerine olanak sağlarlar: yani bir kültürdeki kişilerin ortaklaşa kabul ettikleri, paylaştıkları mitler ve değerler aracılığıyla o kültürün üyesi olduklarını teşhis etmelerine imkân sağlarlar."39

\footnotetext{
${ }^{36}$ Saussure, Genel Dilbilim Dersleri, çev. Berke Vardar, 1/70.

${ }^{37}$ Akt. Robert Hodge, Gunther Kress, Social Semiotics (Ithaca: Cornell University, 1988), 19.

${ }^{38}$ Ahmet Oktay, Popüler Kültürden TV Sömürgesine (İstanbul: İthaki Yayınları, 2009), 330.

${ }^{39}$ John Fiske, İletişim Çalışmalarına Giriş, çev. Süleyman İrvan (Ankara: Ark Yayıncılık, 1990), 219.
} 
İdeolojinin en yaygın ve görünmez pratiklerinden biri yapısalcılar tarafından "çağırma" olarak tespit edilir. Althusser bu durumu "ideoloji öyle "eyler" veya "işler" ki, bireylerin içinden özneler "toplar" ya da bireyleri öznelere dönüştürür ve bunu da çağırma dediğimiz son derece kesin bir işlem yoluyla gerçekleştirir." ${ }^{40}$ şeklinde ifade eder. Bu durum bütün iletişim biçimlerinde geçerlidir. Her iletişim birine seslenir ve seslenilen kişiyi belirli bir ilişki içine yerleştirir. Göstergeler üzerinden söylenecek olursa, bir göstergede bulunan anlamlar, göstergenin ve seslendiği kişinin içinde var olduğu ideolojiden türemektedir. Bu noktada çalışmanın teorik çerçevesini oluşturmada başvurulan Saussure'ün göstergenin bağlı olunan kültür ya da alt kültür tarafından üretildiği şeklindeki tezi anlam kazanmaktadır. Göstergenin toplumsal/iletişimsel yanı önemlidir. Biçimle içerik arasındaki bağlantı özellikle dil göstergelerinde bir uzlaşmaya, o dili kullanan topluluk üyeleri arasındaki gizli-eski bir sözleşmeye dayandığına dair ilke de tekrar hatırlanmalıdır. İletilerin okunması ve anlamlandırılması metin ve izleyicinin karşılıklı etkileşiminden üretilmektedir. “Metin ve izleyici su geçirmez biçimde kaynaşmış bir kültürün ya da alt kültürün üyesi olduklarında bu etkileşim sorunsuz ve zahmetsizdir." ${ }^{41}$

Saussure'ün dilbilim ilkelerinin göstergebilim alanında işletilebileceğine dair tespiti karikatürlerin ve diğer görüntüsel göstergelerin analizine imkân tanımaktadır. "Osmanlı" göstergesinin takip edildiği çalışmada özellikle sarık, cübbe, fes, tespih, takke, şalvar ve sakal gösterenleri taranmaktadır. Adı geçen gösterenlere Osmanlı'nın işlendiği karikatürlerin, çalışmanın kapsamı dışında tutulan karikatürler de dahil, hemen hepsinde yer verildiği gözlenmiş ve bu durum söz konusu öğelerin Osmanlı göstergesinin temel gösterenleri olarak kabulüne imkân tanımıştır. Tespit edilen gösterenlerin gerek Osmanlı gerekse Osmanlı'dan bağımsız olarak taşımış olduğu dini/İslami karakter metinde din, İslam ve Osmanlı eşitlemesi üzerinden bir okuma yapmayı gerekli kılmaktadır. Türkiye'de 1930'lu yıllardaki bir dizi Kemalist literatür/egemen söylem ile pekiştirilen din/İslam/Osmanlı eşitliği de bu şekildeki bir okumanın gerekliliğinin altını çizmektedir. ${ }^{42}$ Osmanlı padişahlarına ve yaşam tarzına dair "mizah" üzerinden getirilen eleştiriler/tenkitler özellikle Cumhuriyet döneminden itibaren süregelen olumsuz söylemlerin temsili ve devamı olarak değerlendirilebilir. Bu noktada karikatürler derginin hitap ettiği ve dergi ile aynı ideolojiye sahip insanlar tarafından "mizah" olarak değerlendirilebilecek olmalarına karşın, bazı kesimlerce rahatsızlıkla karşılanacaktır. Karikatür göstergelerinin içindeki gösteren ve gösterilenler arasındaki ilişki dergi ile aynı ideolojiyi paylaşan insanlar tarafından anlıksal

\footnotetext{
${ }^{40}$ Louis Althusser, İdeoloji ve Devletin Ídeolojik Aygltlarl, çev. Alp Tümertekin (İstanbul: İthaki Yayınları, 2014), 81.

${ }^{41}$ Fiske, İletişim Çalışmalarına Giriş, çev. Süleyman İrvan, 211.

${ }^{42}$ Detaylı bilgi için bk. Öğüt, İnkılâp Kitaplarında Din: 1930’lu Yıllar.
} 
olarak ve nedensiz bir şekilde anlaşılacaktır. Saussure'ün gösterilenin, gösterenin işaret ettiği zihinsel kodların, ortak kültürü paylaşan ve ortak dili konuşan bireylerce aynı şekilde algılanacağına dair tezi bu duruma işaret etmektedir.

Sarık, cübbe, fes, tespih, takke, şalvar ve sakal gösterenleri esasında dini/İslamî karakter taşıyan giyim unsurları şeklindeki bir gösterilene işaret etmekte iken, bu iki unsurun birleşiminden oluşan gösterge Osmanlı göstergesi olarak okunabilecektir. Burada Osmanlı göstergesi noktasında sözgelimi fes göstereni ile din arasındaki ilişki nedensiz ve özellikle bu coğrafya üzerinde bir toplumsal uzlaşıya dayanmaktadır. Gösterge, gösteren ile gösterilen arasındaki eşdeğerlik ilişkisinin toplumsal olarak kurallaşmasından, yerleşmesinden meydana gelmektedir. ${ }^{43} \mathrm{Bu}$ noktada gösteren ile gösterilen arasındaki ilişkinin kurallaşması ve oluşan toplumsal uzlaşının kaynağı olması bakımından 1930'lu yıllara ve Kemalist literatür/Kemalist ideolojiye işaret etmek gerekmektedir. Saussure'ün çağrışımsal (paradigmatik) bağıntısı üzerinden değerlendirildiğinde metinde dikkate alınan gösterenlerden olan sarık, cübbe, fes, tespih, takke, şalvar, sakal gösterenlerini; gösterilen kısmındaki din/İslam da tarih, İslam tarihi, Şark, gericilik benzeri kodları açı̆̆a çıarmaktadır. Guiraud'un ifadesiyle gösterge bir uyarıcıdır, insanın beyninde uyandırmış olduğu zihinsel imge esasında zihinde başka bir uyarıcının imgesine bağlanmaktadır. Göstergenin işlevi ise gerçekleşen bu iletişim doğrultusunda ikinci imgeyi uyarmaktır. ${ }^{44}$

Uykusuz dergisi karikatürlerinde takip edilecek Osmanlı algısının oluşturulduğu yıllar olarak 1930'lar, Cumhuriyet ideolojisi/Kemalist ideolojinin oluştuğu, halka sunulduğu ve benimsetilmeye çalışıldığı yıllar olarak okunabilir. Modernleşme ile dinileşmenin birlikte yürüdüğü Osmanlı Batılılaşmasının ardından, dinin en iyi ihtimalle paranteze alınması ile yürütülen bir Batılılaşma hareketi olarak Kemalist devrim/Cumhuriyet ideolojisi dinin varoluşsal bir gerçek olduğu Türkiye coğrafyasında büyük bir değişim meydana getirmiştir. $\mathrm{Bu}$ değişimin anlaşılabileceği ve takip edilebileceği en önemli tarih dilimi ise 1930'lar Türkiyesi'dir. ${ }^{45}$ Cumhuriyet Halk Fırkası 1930 yılına gelindiğinde ekonomik sorunları çözme ve halka inkılapları benimsetme hususundaki yetersizliği fark etmiş, rejimin tehlikede olduğuna yönelik bir endişeye kapılmış ve Cumhuriyet'in sağlam temellere oturtulması için önlemler alma yoluna gitmiştir. ${ }^{46} 1930$ 'lu yıllarda bir kısmı devlet destekli bir kısmı bağımsız yazılan bir dizi yayında Türk devrimi, inkılaplar ve Mustafa Kemal anlatılmaya, tanıtılmaya çalışılmıştır. Osmanlı Devleti'nin meşruiyetini hedefleyen mevzubahis eserler, Kemalist ideolojinin önemli göstergeleri arasındadır.

\footnotetext{
${ }^{43}$ Rosalind Coward \& John Ellis, Dil ve Maddecilik, çev. Esen Tarım, 29.

${ }^{44}$ Pierre Guiraud, Göstergebilim, çev. Mehmet Yalçın (Sivas: M. Y. Özel Yayım, 1990), 31.

45 Öğ̈̈, Inkılâp Kitaplarında Din: 1930'lu Yıllar, 15.

${ }^{46}$ Hakan Uzun, “Tek Parti Döneminde Yapılan Cumhuriyet Halk Partisi Kongreleri Temelinde Değişmez Genel Başkanlık ve Milli Şef Kavramları, ÇATTAD IX/20-21 (Bahar-Güz, 2010), 239.
} 
Çalışmada Osmanlı gösterenleri olarak kabul edilen sarık, cübbe, fes, sakal, tespih, takke, şalvar gerek dönemin Tarih ders kitaplarında gerekse adı geçen literatürde şapka inkılabı üzerinden ele alınmaktadır. Osmanlı dönemindeki uygulamalar anlatılırken "Isşte fes Türk'ün başına bu suretle bela oldu", "Fes hiç sevilmeksizin katlanılmasına alışılmış belalardandı" şeklinde ifadelere yer verilmekte, fesi kullanmaktan memnun olmayan bir halk tasvir edilmektedir. Bu durumu ve yapılan inkılabın büyüklüğünü göstermek için “Türkiye' de dinî ve millî bir damga haline konulması için o kadar çalışılmış olan fesin bir hamlede sökülüp atılabileceği hiç kimsenin aklından geçmiyordu" ${ }^{47}$ ifadeleri kullanılmaktadır. Burhan Cahit eserinde Mustafa Kemal'in takke, fes ve sarı̆̆ medeni olmadıkları noktasındaki eleştirisine ve bununla bağlantılı olarak fikrin ve zihniyetin tepeden tırnağa medeni olması gerektiğine dair uyarısına yer vermektedir. Aynı konuşmada Mustafa Kemal, Türk ve İslam aleminin zihniyetlerini medeniyetin emrettiği şekilde değiştirmemelerinden kaynaklanan geriliğine işaret etmekte, Türk toplumunun bu geriliği medeniyet yolunda eritmesi gerektiğine vurgu yapmaktadır. ${ }^{48}$ Buradaki medenilikten kasıt, söz konusu literatürde Avrupalılık olarak şerh edilmekte, Engin bu durumu "Bu inkılap tam manası ile Avrupalılıktır" ${ }^{49}$ ifadeleriyle netleştirmektedir. 1912-1931 tarihleri arasında Türk Ocakları başkanlığı görevini yürüten Hamdullah Suphi Tanrı̈ver de Engin'den daha erken bir tarihte Türklerin ancak Avrupalı bir toplum olduktan sonra Türklüklerini keşfettiklerini belirtmektedir.

Mediha Muzaffer güneş ve hayat ışığını alamayan kafesli evlerin, din ve tesettür ruhunu aşılayan peçeli çarşafların, fesler, sarıklar, perdeli tramvayların Türk milletinin hayatının çok kıymetli zamanlarını ziyan edip, insanca yaşamaktan alıkoymasının yanında medenice yaşamayı engellediğine yer vermekte ve tüm bunların kaynağı olarak da din, anane ve bunlardan beslenen kadercilik ve taassubu göstermektedir. ${ }^{50}$ Mediha Muzaffer tarafından "eski kıyafet garabeti" olarak verilen giyim kuşamdan kurtuluşu Cavit Aker “Şark'ın köhne kokmuş adetlerinden ahlâklarından kurtulduk. Şimdiye kadar Türk milletinin görmediği bir huzur ve saadete kavuştuk" ${ }^{51}$ şeklinde ifade etmektedir. Fuat Hulusi, Cumhuriyet'in Türk milletini insan kılığına soktuğunu "milliyetin herkesten ayrı ve gülünç giyinişte değil, imanlı yüreğin ve sağlam kafanın içinde, iffetin ve temizliğin başörtüsünde, peçe ve çarşafta değil, açık alında ve aydınlıkta olduğunu" öğrettiğine yer verir, püsküllü kızıl belayı Türk milletinin başından atmasından ötürü şükranlarını ifade

\footnotetext{
${ }^{47}$ Tarih IV (İstanbul: Devlet Matbaası, 1931), 230-231. Benzeri anlatımlar için bk. Burhan Cahit, Mudanya, Lozan, Ankara (İstanbul, 1933), 1-54.

${ }^{48}$ Bk. Burhan Cahit, Mudanya, Lozan, Ankara, 232.

${ }^{49}$ Saffet Engin, Kemalizm İnklabının Prensipleri (İstanbul: Cumhuriyet Matbaası, 1938), 2/240.

${ }^{50}$ Mediha Muzaffer, Inkılabın Ruhu (İstanbul: Devlet Matbaası, 1933), 61.

${ }^{51}$ Cavit Aker, Inkılabımız Hakkında Köylüye Öğütler (Muğla: Halk Basımevi, 1936), 34.
} 
eder. ${ }^{52}$ Vasfi Mahir'in "Cumhuriyet Bayramı Temsili" ismiyle kaleme aldı̆̆ 1 oyundaki ifadeleri konu açısından önem arz etmektedir:

“Ben şapka inkılâbını hazırladım. Babama sordum; birçok kitaplar okudum; öğrendim ki biz eskiden şapka değil, fes, sarık, külah, kavuk daha bilmem neler giyermişiz. İnsanlar arasında kıyafetin elbette bir tesiri var. Kafamızın içini ne kadar işlersek işleyelim, ona medenî bir kıyafet vermeden kendimizi tanıtamaz ve sözümüzü dinletemeyiz. Avrupalılar bizi öyle misır koçanı gibi uzun püsküllü, kıpkırmızı bir fesle, üç etek cübbelerle, yedi arşın mermer şahi sarıkla görünce pek haklı olarak ehemmiyet vermez ve bundan yüz, üç yüz sene evvelki adamlar zannederlermiş. Ben bile bugün o eski kavuklu şalvarlı resimleri görünce ne kadar gülüyorum. Geçen gün bizim eski kıyafetimizde gezen iki şarklı seyyah gördüm de Karagözle Hacivat sokağa çıkmış sandım. Asıl mesele: Cahil ve mütaassıp halk bu kıyafetin değişmesini eskiden beri istemezmiş. Bilhassa başına şapka geçirenler gâvur sayılır ve öldürülürmüş. Bugün memleketimize gelen bazı yabancılar, karşılarında aynen Berlin, Paris sokaklarındaki adamları görünce kendilerini henüz bir Avrupa şehrinde zannederek Türkiye'ye ne zaman çıkacaklarını soruyorlar." 53

Yukarıda 1930'lu yıllarda oluşan literatürden örneklerle yer verilen hususların hepsinin kaynağı olarak görülen padişaha dair çizilen portre "eğitim seviyeleri, üç beş satır kargacık burgacık yazıyı bile dört beş imla yanlışı yapmadan okuyamayacak kadar düşük, çoğu zaman kendi zevklerini düşünen, zevkleri uğruna tebaasının malını canının istediği gibi kullanmaktan çekinmeyen, bir kısmı aklı başında olmayan, kimi zaman nereden geldikleri belli olmayan ana ve karılarının ellerinde oyuncağa dönüşen bir padişah" şeklindedir. ${ }^{54}$ Osmanlı temsilinin en önemli göstereni olarak padişah çizimlerinin de söz konusu literatürde oluşturulan padişah profilinden izler taşıdığ1 görülmektedir. Muallim Galip Naşit'in Cumhuriyet'in onuncu yılı münasebetiyle kaleme aldığı piyeste padişahlar genel olarak "bunak dervişler ve zevkleri kelle vurdurmak ve kan dökmek" olan insanlar şeklinde tanımlanırken, yükselme dönemi padişahı olan Fatih Sultan Mehmet "otağının en gölgeli yerinde, kuş tüyü minderinde keyif çatan padişah" olarak tasvir edilmektedir. ${ }^{55}$ Atalet ve miskinlik ise Osmanlıya dair sıkça kullanılan ifadeler arasında ilk sıralarda yer

\footnotetext{
${ }^{52}$ Fuat Hulusi, Yılların Dili (İstanbul: Devlet Matbaas1, 1933), 44-45.

${ }^{53}$ Vasfi Mahir, 10 Ínkılap (İstanbul: Ankara Matbaası, 1933), 8-9; Benzeri tasvirler için bk. Vedat Nedim, 29 Birinci Teşrin (Ankara: Köy Hocası Matbaası, 1933), 16; Burhan Cahit, Mudanya, Lozan, Ankara, 51.

${ }^{54}$ Bk. Öğüt, İnklâp Kitaplarında Din: 1930’lu Yıllar, 68.

${ }^{55}$ Galip Naşit, Destan (İstanbul Devlet Matbaası, 1933), 12
} 
almaktadır. Osmanlı padişahlarının çevrelerine korku salmaları, İmparatorluğun adeta bir "korku imparatorluğu" olduğuna yönelik ifadeler ise padişah başlığı altında ilk zikredilen hususlardandir. ${ }^{56}$

Her fikirsel oluşum ve her ideolojik tutunma gayreti kendine tarihi bir istinat zemini bulmak zorundadır. ${ }^{57}$ Cavit Aker'in "Türk milletinin görmediği huzur ve saadete kavuşması" şeklindeki ifadesi Cumhuriyet ideolojisinin tarih anlayışına işaret etmektedir. Söz konusu literatürdeki bir başka eserde Türk devrimi ile Türk milletinin ulusal tarihinin akışının değiştirildiğine ve Türk devriminin Türk'e yalnız talihini değil, tarihini de verdiği belirtilmektedir. ${ }^{58}$ Kemalist ideolojinin tarih anlayışının ilk planda Comte'çu bir temele dayandığı söylenebilir. İnsanlığın geçirmiş olduğu evrelere dair Comte sosyolojisinde, teolojik, metafizik ve pozitif dönem şeklinde yapılan tasnif kabul edilmekte, Osmanlı dönemi metafizik döneme yerleştirilmekte ve tabiri caizse bu dönemde kalmakta gösterdiği 1srar sebebiyle de suçlu kabul edilmektedir. Nihayetinde Osmanlı tek mabutlu bir dinin çizdiği planlar içinde teneffüs eden, hukukunun, iktisadının, siyasetinin, dilinin ve estetiğinin hep dini mahiyette olduğu bir yapı arz etmektedir. ${ }^{59}$ İlerlemeci bir tarih anlayışı temelinde kurulan bir mantık çerçevesinde yapılan Osmanlı kritiği neticesinde, Osmanlı pozitif ve demokratik-endüstriyel-cumhuriyet dönemine doğru sekülerleşme, demokratikleşme ve sanayileşme bağlamında ilerlemesi gerekirken, Osmanlı Devleti'nin rolünü icra edemediği tespit edilmektedir. Beşerî medeniyet devirlerinin ilk ikisinin yaratıcısı ve yayıcısı olan Türk milleti, Osmanlı Devleti tarafından engellenmiş, metafizik dönemin gereği olan kritiği gerçekleştirememiş, bu dönemde aşılması gereken ilahi hukuk ve otoritenin esiri olmuştur. Bu minvalde Mehmet İzzet de Türk ırkını tarih sahnesindeki rolüne geç kalan bir aktöre benzetmektedir. ${ }^{60}$ Kaybedilen bu dönem Kemalist inkılaplar ile aşılmış, geç kaldığı tarihi yolculuğunu hızla tamamlamıştır. Ait olduğu sanayileşme, maddi refah ve demokrasi, laiklik, hür ve müspet (pozitivist) zihniyetin temsili olan Cumhuriyet devrine geçiş yapmıştır. ${ }^{61}$

Burhan Cahit'in “Osmanlı saltanatı devirlerinde Türk milletinin terbiyesini çöl kabilelerinin adetlerine göre vermeye çalışan dar fikirli başbuğlar milletler tarihini alt üst eden büyük Türk varlığını dar bir Mekke ve Kazvin havzası içinde boğmaya çalıştılar.

\footnotetext{
${ }^{56}$ Bk. Yaşar Nabi, Inkılâp Çocukları (Hakimiyet-i Milliye Matbaası, 1933), 12-13; Beş Devir, 7; Ali Zühtü \& Müçteba Selahattin, Tarih Utandı (İstanbul: Devlet Matbaası, 1933), 6; Mediha Muzaffer, Ínkılâbın Ruhu, 45; Aker, Inkılâbımız Hakkında Köylüye Ögütler, 1.

${ }^{57}$ Seyfullah Kara, "Milli Tarih Anlayışının Romantik Devri: Cumhuriyetin İlk Yılları", Atatürk Üniversitesi Türkiyat Araştırmaları Enstitüsü Dergisi 11/ 13 (2004), 320.

${ }^{58}$ Eyüp Hamdi Akman, Türk Devrimi ve Devrimciliği (İzmir: Meşher Basımevi, 1936), 13.

${ }^{59}$ Bk. Sadri Etem, Türk Inkılabının Karakterleri (İstanbul: Devlet Matbaası, 1933), 51.

${ }^{60}$ Orhan Koçak, “1920’lerden 1970’lere Kültür Politikaları”, Modern Türkiye'de Siyasi Düşünce: Kemalizm, ed. Tanıl Bora \& Murat Gültekingil (İstanbul: İletişim Yayınları, 2009), 2/371.

${ }^{61}$ Detay için bk. Saffet Engin, Kemalizm Ínkılabının Prensipleri, 1/39-233.
} 
Dünyayı yalnız din çerçevesinde gördüler."62 ifadeleri Türklerin Müslüman olduktan sonra dini/İslam'ı milli unsurlarının önüne geçirmeye başlamaları ve Osmanlı döneminin bunun zirve dönemi oluşu, Cumhuriyet ideolojisindeki gayrı millilik ve dinilik eşitliğini ${ }^{63}$ göstermesi bakımından önemli olmakla birlikte, atıfta bulunulan dönem ve meşruiyet kaynağı olarak, Türk Tarih Tezi'nin de işaret ettiği üzere Türk göçlerine yapılan vurguyu da içermektedir. ${ }^{64}$ Mediha Muzaffer'in “Osmanlı istiklâli demek Türk'ün asırlardan beri devam eden siyasî ve içtimaî hayatını kısaltmak ve küçültmektir" ${ }^{65}$ şeklindeki satırları Kemalist tarih anlayışının Osmanlı algısına dair en net ifadeleri olarak değerlendirilebilir. Türk milletinin Osmanlı tarihinin başlangıcına arızî olarak karıştığına dair bir iddianın varlığını da burada kaydetmek gerekmektedir. ${ }^{66} \mathrm{Bu}$ iddiaya göre bu arıiyet tarihin seyri boyunca da devam etmiştir. İslam tarihi ise Araplara ve Araplığa ait tarih olarak tanımlanmaktadır. Ali Rıza Seyfi'nin Türklerin dedelerinin dillerini ve illerini unutturacak dini ve siyasi amillerin tarihleri boyunca hep var olduğuna ${ }^{67}$ dair vurgusu da aynı doğrultudadır.

Osmanlı Devleti'nin başlangıcı liseler için hazırlanan Tarih ders kitabında şu şekilde anlatılmaktadır: “Osmanlı Devleti'ni tesis eden ve sonradan Osmanlı namını alan Türklerin nereden ve ne zaman Anadolu'ya geldikleri henüz ilmî bir surette tespit edilebilmiş değildir. Bu Türk aşiretinin de bütün Türkler gibi Orta Asya'dan İran yoluyla garba ilerleyerek aşiret reisi Ertuğrul Bey'in emri altında Anadolu'ya gelip yerleşmiş olduğu rivayet edilmektedir. Osmanlı hükümdarlarının Oğuz Han'a kadar giden bir silsilenameleri varsa da bu sonradan uydurulmuş bir şeceredir." 68 Akman'ın ifadesiyle Türk'e tarihini geri veren Cumhuriyet ideolojisinin, Türk milletinin tarihine yönelik çizmiş olduğu çerçevede Osmanlı çok küçük bir alanı şamildi. İslamcıların Asr-1 saadete ve kaynaklara dönüş hareketini hatırlatır bir

\footnotetext{
${ }^{62}$ Burhan Cahit, Mudanya-Lozan-Ankara, 11-12.

${ }^{63}$ Halil Nimetullah, Halkçılık ve Cumhuriyet ve Türk Halkçıllğı ve Cumhuriyeti (İstanbul: Devlet Matbaası, 1930), 53, 58, 81 .

${ }^{64}$ Detay için bk. Saffet Engin, Kemalizm İnkılabının Prensipleri, 2/3-15; Türk Tarihinin Ana Hatları (İstanbul: Devlet Matbaas1, 1930), 49-60; Suat Tahsin, Türkiye Cumhuriyeti Banisi Gazi Mustafa Kemal (İstanbul: Akşam Matbaası, 1933), 5; Şaziye Berin, Baybiçe (İstanbul: Devlet Matbaası, 1933), 6.

${ }^{65}$ Mediha Muzaffer, İnkilâbın Ruhu, 37.

${ }^{66}$ Resimlerle de desteklenen Osmanlı Imparatorluğu'ndan Türkiye Cumhuriyeti'ne Nasıldı Nasll Oldu 10 isimli eserde, Osmanlının tarih telakkisi "Osmanlı tarihi, İslam tarihi ve Umumi tarih" olmak üzere üç bölüme ayrılmaktadır. Osmanlı tarihi Osmanoğulları'nın bir aile masalından ibaret iken, Osmanlı cemiyetinin teokrasiye verdiği mevki neticesinde mühim saydığı İslam tarihi baştan aşağı Araplara ve Araplığa aittir. Umumî tarih ise gerek hareket gerekse verdiği hükümler bakımından gayrı ilmî keyfî olan bir Avrupalılık tarihidir. Kitapta Arap harfleri ile yazılmış olan iki sayfanın resimleri ile desteklenen Osmanlının tarih anlayışının hemen yanında Türk Tarihi Tetkik Cemiyeti tarafından 1932 tarihinde bastırılan dört ciltlik lise Tarih ders kitabının resimleri ile destekli inkılapçı Türk'ün tarih anlayışı yer almaktadır. İnkılâp Türkiyesi'nin tarih görüşünün hareket noktası, Türk milletinin tarih sahnesine çıkışı, mihver ve varış noktası ise "Türk milletinin insanlık tarihinde oynadığı ve oynamakta olduğu medeniyet”tir. Osmanlı tarihi, İslam tarihi ve Araplılık tarihi ise Türk tarihinin içine ancak bir fasıla olarak girebilir. Bk. Maarif Vekaleti, Osmanlı Imparatorluğu'ndan Türkiye Cumhuriyeti'ne Nasıldı Nasıl Oldu? 10 (İstanbul: Devlet Matbaası, 1933), 36-37.

${ }^{67}$ Ali Rıza Seyfi, Gazi ve İnkllap (İstanbul: Sinan Matbaası ve Kütüphanesi, 1933), 97.

${ }^{68}$ Tarih III (İstanbul: Devlet Matbaası, 1932), 1.
} 
tarzda, Osmanlı adeta yok sayılmakta ve Orta Asya'ya vurgu yapılmaktadır. Dört cilt olarak hazırlanan ancak yeterli görülmediği için okullarda okutulmayan, daha sonra özeti çıkarılarak otuz bin adet basım yapılan 605 sayfalık Türk Tarihinin Ana Hatları kitabının Orta Asya'ya ayrılan bölümü 205 sayfa, diğer uygarlıkların Türk kökenlerine ayrılan bölümü 100 sayfa, Osmanlı tarihine ayrılan bölüm ise 50 sayfadır. ${ }^{69}$ Burada orta mekteplerde okutulmak için Hamit ve Muhsin tarafından hazırlanan Türkiye Tarihi ${ }^{70}$ isimli eserden de bahsetmek gerekir. Bu eser esasında 1924 yılında Arap harfleriyle ve resimsiz olarak basılmış, 1926 tarihinde düzeltilerek tekrar yayınlanmış, nihayetinde 1930 yılında Türk harfleri ile yayınlanmıştır. 752 sayfalık eserin ağırlıklı kısmı Osmanlı Devleti'ne ayrılmış ve fakat Osmanlı tarihi yükselme döneminden itibaren anlatılmaya başlanmıştır. Çalışma boyunca bahsi geçen kaynakların aksine, yayın yılı sebebiyle olsa gerek, Osmanlıya dair ağır ifadelerle bu eserde karşılaşılmamakla birlikte, padişah üzerinden anlatım bilinçli bir şekilde tercih edilmediği ve fakat eserde II. Abdülhamid ve Vahdettin'e dair olumsuz ifadeler kullanıldığı gözlenmektedir.

Cafer Sadık Kırcaali Gençliğe İnkılâp Vecizeleri kitabında inkılabın esas gayesini “Türk ulusunun ruhunda gizli kalan büyük varlıklarını garba ve acuna tanıtmak" şeklinde tespit etmektedir. Kırcaali ve diğer birçok Kemalist yazar “Türk'ün ruhundaki büyük varlığını açığa çıkaramamasının" sebebi olarak Osmanlı Devleti'ne işaret etmektedir. Devletin tek mabutlu bir dinin çizdiği planlar içerisinde teneffüs etmesi, hukukunun, iktisadının, siyasetinin, dilinin ve estetiğinin hep dinî bir karakter arz etmesi ${ }^{71}$ Kemalist literatür tarafından Türk'ün önündeki engel olarak tespit edilmektedir. Hatta bu durum yer yer “diri diri beyaz kefenin giyilmesi"72 şeklinde nitelendirilmektedir.

Osmanlı devlet modeli üzerine eğilen Halil Nimetullah'a ait “Cemiyet hayatının bazen öyle devreleri olur ki içtimaî varlık kaybolmuş, millî şuur doğmamış, cemiyet kendi benliğini unutmuş olarak yabancı unsurların, yâd kaidelerin cemiyette teşkil ettiğ gayrı millî müesseseler gûya cemiyetin kendi mevcudiyeti imiş gibi bütün fertlere hâkim olurlar. Fertler bu gayrı millî müesseselerin tasallutu altında kendi öz varlıklarına sahip olamamak ve bununla beraber o tahakkümün altından kurtulamamak ıztırarı ile ezici bir hava içinde yaşarlar. İşte "Osmanlı cemiyeti” zamanındaki Türk hayatı böyle olup bir taraftan yabancı

\footnotetext{
${ }^{69}$ Detaylı bilgi için bk. İsmail Hakkı Uzunçarşıll, “Türk Tarihi Yazılırken Atatürk’ün Alaka ve Görüşlerine Dair Hatıralar”, Milli Tarihin İnşası, ed. Ahmet Şimşek \& Ali Satan (İstanbul: Tarihçi Kitabevi, 2011), 181-188.

${ }^{70}$ Hamit \& Muhsin, Türkiye Tarihi (İstanbul: Devlet Matbaası, 1930).

${ }^{71}$ Sadri Etem, Türk Inkılâbının Karakterleri, 51.

${ }^{72}$ Yaşar Nabi, Beş Devir, 9. Benzeri anlatımlar için bk. Cevat Hakkı, Inkılâbımız Hakkında Köylüye Öğütler, 10 , 100; Etem İzzet, On Yılın Romanı (İstanbul: Devlet Matbaası, 1933), 100-101; Mediha Muzaffer, Inkılâbın Ruhu, 7, 48, 59-60; Halit Fahri, On Yılın Destanı (Ankara: Hakimiyet-i Milliye Matbaası, 1933), 22; Şaziye Berin, Baybiçe, 20; Burhan Cahit, Mudanya-Lozan-Ankara, 35; Maarif Vekaleti, Osmanlı İmparatorluğu'ndan Türkiye Cumhuriyeti'ne Nasıldı? Nasıl Oldu? 10, 28-29.
} 
muhitlerden alınmış, diğer taraftan arta kalmış olan birtakım yabancı unsurların, arta kalmış kaidelerin sultası altında millî varlık kendini göstermiyor, dağınık ve âvâre bir halde kalıyordu. Fertler kendi varlıklarını bu yabancı unsurların içinde kaybetmiş, benliğini unutmuş olarak bulunduğu eğreti hayatı heyecansız bir halde yaşarlardı. Asıl cemiyet hayatı ise canlı unsurlardan mahrum, artık içtimaî varlıklarla alâkası kalmamış olan köhne örflere, yâd kaidelere tâbi ve fertlere kendi varlığını telkin edemez, sönük ve kapanık bir mevcudiyet idi." 73 şeklindeki ifadelerin temel eleştiri noktası, yazarın ifadesiyle, "teokratik bir devlet modeli"dir. Bir başka şekilde söylenecek olunursa yazarın altını çizdiği husus, dinî/İslamî devlet yapısının Türk varlığına verdiği zarardır. Taassup örümceğinin ağları ile örülen siyasi ve toplumsal düzen ile Türk cemiyeti şeriatın, mecellenin ve fetvanın taşlaşmış kalıpları içerisine sıkıştırılmıştır. ${ }^{74}$ Burhan Cahit Osmanlı ile Türk'ün şahdamarlarının Asya'nın iptidaî cemiyet ve din bağları ile dügü̈mlendiğine ve Türk'ün ruhundaki yükselme kabiliyetinin Şark'ın kalın ve kuvvetli havasının içinde boğulduğuna yer vermektedir. ${ }^{75}$ Sadri Etem'in Osmanlı devlet teşkilatını saray, medrese ve yeniçeri olarak üçe ayırması, bu üç kurumu devletin halkını cahil bırakma amacı üzerinde birleşmiş kurumlar olarak tanımlaması önemli bir noktaya işaret etmektedir. Zira Etem'in tasnifine göre bu üç kurumun da ortak özelliği veya bu üç kurumun çatısını din/İslam oluşturmaktadır. Osmanlı Devleti'ne yönelik, çalışmada özellikle dikkate alınan, Kemalist literatür tarafından getirilen temel tenkit noktası, literatürün kendisine "şeriatçılık"76 adını verdiği, devletin dinî/İslamî karakteridir. Osmanlı Devleti'nin Türk tarihinde oynamış olduğu rol en kısa ifadesiyle "utanılası" ve "yampiri bir çıkış" olarak nitelendirilmektedir.

Osmanlının toplum nazarındaki meşruiyetini yıkma şeklinde bir paydada buluşan bu eserler, Althusser'in kültürel DİA kapsamına dahil edilebilecektir. Yukarıda Osmanlıya dair verilen alıntılar, resmî ideolojinin Osmanlı algısını yansıtma yanında Osmanlıya karşı duyulan öfkenin sebebi olarak da okunabilir. İdeolojiye can veren göstergeler olarak 1930’lu yıllarda yazılan bu eserlerde kurulan söylemler çalışmada temel alınan Uykusuz dergisinde de takip edilebilmektedir. Bu noktada çalışmanın devamında Cumhuriyet ideolojisinin Osmanlıya dair çizmiş olduğu söylemsel çerçeve karikatürler üzerinden takip edilmeye çalışılacaktır.

\footnotetext{
${ }^{73}$ Halil Nimetullah, Halkçılık ve Cumhuriyet ve Türk Halkçılığı ve Cumhuriyeti, 67.

${ }^{74}$ Maarif Vekaleti, Osmanlı Imparatorluğu'ndan Türkiye Cumhuriyeti'ne Nasıldı? Nasıl Oldu? 10, 20.

${ }^{75}$ Burhan Cahit, Mudanya-Lozan-Ankara, 43. Yazar Asya'nın iptidailiği ile kastettiği hususa Kemalizm'in Yeni Türkiye Devleti'ne yönelik hedeflerini açıklarken şu şekilde yer vermektedir: "Yeni Türk Devleti'nin Arap, Acem, Buhara gibi Asyaî teşekküllerden ayırmak be yan yana yaşadığı muasır, medeni cemiyetlerin hayatına kaynaştırmak lazım" Burhan Cahit, Mudanya-Lozan- Ankara, 35.

${ }^{76}$ 1930'lu yıllarda yazılan Kemalist literatür, Türk inkılabı ile İslam'ın değil, Osmanlı din/İslam anlayışının hedeflendiğinin altını çizmekte ve Osmanlı din anlayışının "şeriatçılık" olarak isimlendirmektedir. Detaylı bilgi için bk. Öğüt, İnkılâp Kitaplarında Din: 1930’lu Yıllar, 191-204.
} 


\section{2015 YILI MAYIS-AĞUSTOS KARIKKATÜRLERİ}

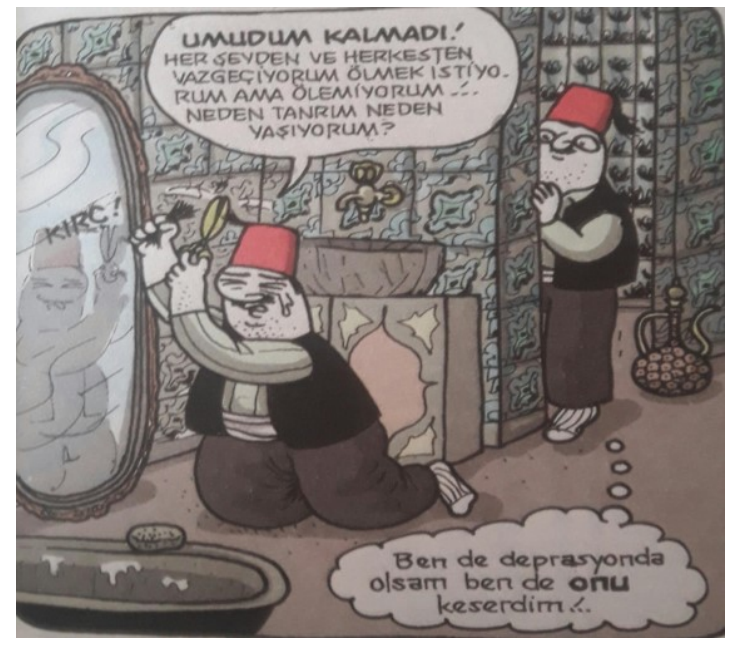

Karikatür 1: Cihan Ceylan, Uykusuz Dergisi, 28 Mayıs 2015, s. 12.

Gösteren: Osmanlı dönemini yansıtan kılık-kıyafet ile görülen iki erkek, ayna, lavabo ve musluk, eski tarz bir küvet ve ibrik.

Gösterilen: Depresyonda olan bir erkeğin kendine zarar vermeye çalışmasıdır.

Yorum: Karikatürde Osmanlı döneminden bir tablo resmedilmeye çalışılmaktadır. Buna göre karikatürde yer alan iki erkek de II. Mahmut dönemi itibari ile şehir halkı tarafından kullanılmaya başlanan fes ile öne çıkarılmaktadır. Şalvar, gömlek, içlerine mendil, para, silah vb. koymak için kullanılan kuşak ve kısa yelek de yine Osmanlı dönemi giyim tarzını yansitan tamamlayıcı unsurlardır. Burada birbirini tamamlayan unsurlar olarak yer verilen iki öğe arasında nedensiz bir ilişki vardır ve özellikle içerisinde bulunulan toplum/kültür özelinde anlamlıdır. Fes göstereni ise karikatürde hem çizim hem de metinsel olarak öne çıkarılmaktadır. Osmanlı ile ilişkisi en güçlü gösteren olarak kabul edilebilecek olan fesin Saussurecü yaklaşım ile, "tepesi düz, püsküllü ve genellikle kırmızı olan başlığa" karşılık gelmekten ziyade muhatabın zihnindeki fese karşılık geldiği bir kez daha belirtilmelidir. Buna ek olarak iletişim ise tamamen zihinsel ve çağrışımsaldır. Osmanlı, İslam, tarih, İslam tarihi, Şark, gericilik, tedirginlik, mutsuzluk ve hüzün çağrıştırdığı kısım olarak verilebilir. Karikatürde ilk planda depresyona giren kadınların bir değişim adına saçlarını kestirmesine atıf yapılıyor gibi görünmektedir. Ancak ikinci karaktere kurdurulan söylem ve fese işaret eden zamirin koyu harflerle yazılması bağlamı buradan uzaklaştırmaktadır. "Her şeyden ve herkesten vazgeçiyorum" ifadesinin karşılığ1 olarak çizer fes püskülüne işaret etmekte ve Osmanlı döneminde fese büyük anlamlar yüklendiği mealini çizimine yansıtmaktadır. Depresyonda olan erkek her şeyden vazgeçme adına ilk olarak fesinin püskülünden 
başlamaktadır. Durumu gözleyen ikinci erkeğin söylemi ise fesi basitleştirme amacına matuf bir söylem olarak okunabilir. Karikatürde yer alan gösterenler, fes ve Osmanlı giyim tarzına dair Cumhuriyet dönemi itibari ile kurulan ve yaygınlık kazanan "mısır koçanı" ve "altı kaval üstü şişhane" söylemlerini hatırlattı̆̆ı da burada belirtilmelidir.

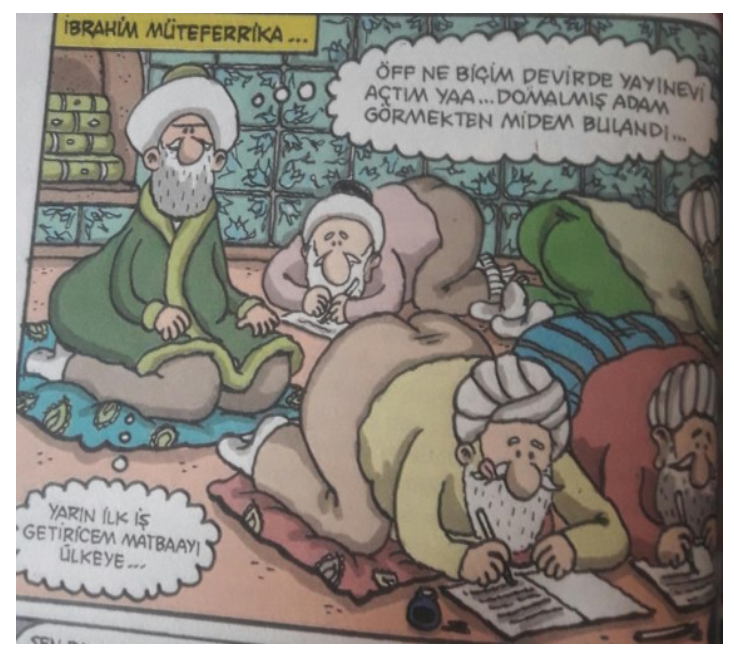

Karikatür 2: İltem Dilek, Uykusuz Dergisi, 18 Haziran 2015, s. 7.

Gösteren: Oturur pozisyonda sarıklı cübbeli yaşlı bir adam, yerde secde pozisyonuna yakın şekilde eğilmiş bir vaziyette yazı yazan dört adam, minderler, kitaplar, kalemler, defterler ve mürekkep.

Gösterilen: Osmanlı dönemindeki yayınevi faaliyetlerinin ilkelliği gösterilmek istenmektedir.

Yorum: Karikatürde oturur pozisyonda çizilen isim, bizzat belirtildiği üzere İbrahim Müteferrika'dır. Bir yayınevi resmedilmeye çalışılmaktadır. "Osmanlıya matbaanın geç gelişi/getirilmek istenmeyişi” şeklindeki müsellem algının karikatürde işlendiği görülmekle birlikte, Müteferrika'nın matbaayı Osmanlıya getirmesi, mizah amacıyla, “domalan adam görmek" gibi cinsel ve aşağılayıcı bir gerekçeye bağlanmaktadır. Sarık, gömlek, bele sarılan kuşak ve şalvar pantolon Osmanlı giyim tarzını yansıtmaktadır ve bir bütün olarak vücut hatlarını belli etmeme üzerine kuruludur. Bu giyim şeklini resmetmekle birlikte, yazı yazan adamların vücut hatlarını belli eder tarzda çizilmeleri cinsel bir aşağılama olarak okunabilir. Cinselliğin, özellikle Türkiye toplumunda, mizahı yakalayabilme adına karikatüristler tarafından sıkça başvurulan bir alan olduğu bilinmekle birlikte, bu başvurunun tarihi bir dönemin işlendiği karikatürler arasında, iyimser bir ifadeyle, ağırlıklı olarak Osmanlı'nın işlendiği karikatürlerde gerçekleşiyor oluşu "cinsel aşağılama" tespitini güçlendiriyor olsa gerektir. Osmanlı geleneğinde katipler tarafından kullanılan bir unsur olarak "rahle/masa" 
figürünün bir gösteren olarak yer almaması ise cinselliğe yapılan vurguyu artırmakta ve aşağılamaya dair bir okumanın imkanını kuvvetlendirmektedir.

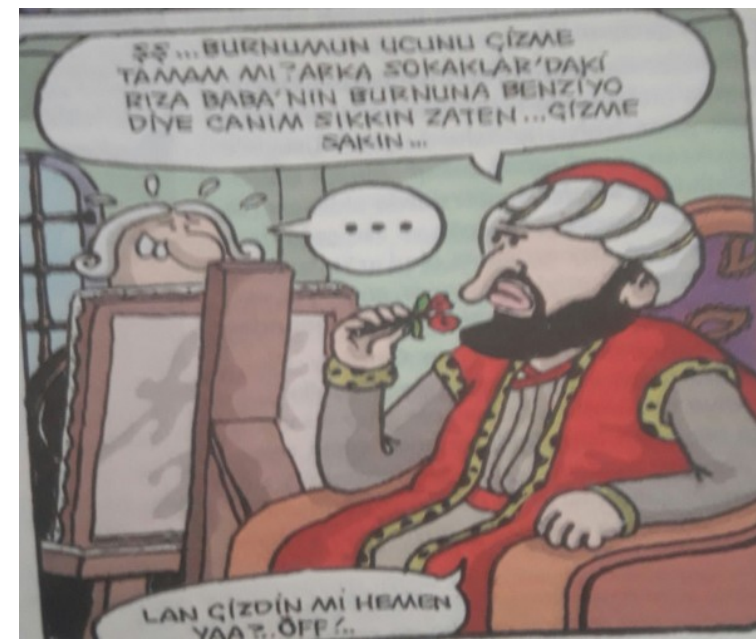

Karikatür 3: İltem Dilek, Uykusuz Dergisi, 2 Temmuz 2015, s. 7.

Gösteren: Poz veren bir padişah, ressam, şövale, taht ve çiçek.

Gösterilen: Kendisini olduğundan farklı ve güzel göstermeye çalışırken, aciz durumlarda kalan padişah ve padişahtan korkan bir ressam resmedilmek istenmektedir.

Yorum: Osmanlı padişahlarından Fatih Sultan Mehmet'in bir çiçeği koklarken çizilen portresi neredeyse herkes tarafından bilinmektedir. Karikatürde resmedilen padişah tiplemesi kanaatimizce mezkûr portreye de atıfta bulunmaktadır. Dünyaca tanınan bir Osmanlı padişahı bir dizi karakterinden daha ünsüz olarak sunulmakta, mantıken Rıza babanin burnunun Fatih'in burnuna benzetilmesi gerekirken, tam tersi yapilmaktadir. Böylelikle Fatih Sultan Mehmet'in geri plana alındığ 1 ve Rıza baba karakterinin ise ön plana çıkarıldığı söylenebilir. Herhangi bir padişah değil de Osmanlı tarihindeki en güçlü ve dolayısıyla en başarılı padişahlardan biri olarak Fatih Sultan Mehmet'in böylesi bir karaktere konu edilmesiyle, Türk toplumunun ağırlıklı bir kesiminin tahayyülündeki güçlü padişah algısının hedeflendiği düşünülebilir. Sözgelimi resim ve gravürlü albümlerin oldukça yaygın ve Avrupalı elçilerin maiyetlerinde veya gezgin olarak İstanbul'a gelen Batılı ressamların sayısının çok olduğu bir dönem olan 18. yüzyıl dönemi ${ }^{77}$ bir padişahtan ziyade Sultan Fatih'in seçilmesi zihinlerde soru işareti oluşturacak tarzda bir tercihtir. Ayrıca karikatürde, özellikle 1930'lu yıllarda oluşturulan Kemalist literatür tarafından keyif düşkünü Osmanlı

\footnotetext{
${ }^{77}$ Selin İpek, "Padişah Portreleri Seksiyonu”, Topkapı Sarayı'nı Anlatmak, ed. Ali Satan, Salim Aydın, Selin İpek (İstanbul: Kültür ve Turizm Bakanlığı, Topkapı Sarayı, 2018), 344.
} 
padişahları ${ }^{78}$ şeklinde kurulan söylemin gerek gösterenler ile gerekse metin olarak korunduğu da gözlemlenmektedir. Ressamın, padişahın dilini anlamaması veya korku içerisinde olması şeklinde iki türlü yoruma da imkân veren karikatürize ediliş şekli yine üzerinde durulması gereken bir husustur. Bildiği yabancı diller ile de üne kavuşmuş bir padişah olarak Fatih Sultan Mehmet'in ressam ile diyaloğunda, ressamın kendi dilinde iletişime girecek olması kuvvetle muhtemeldir. Bu durum ressamın çiziliş şeklinin padişaha karşı duyduğu korkuya işaret ettiği düşünülebilecektir. Uykusuz dergisi karikatürlerinin Osmanlı padişahlarını konu alan karikatürlerine yapılacak bütüncül bir bakış da bu tespiti destekleyecektir. Bu çalışmada temel alınan Kemalist literatürün Osmanlı padişahlarına dair geliştirdikleri "korkunç, zalim, müstebit padişah" söylemleri bu noktada hatırlanmalıdır. Karikatürde padişah tarafından söylenilen sözler de sanattan bihaber bir padişah algısını desteklemektedir.

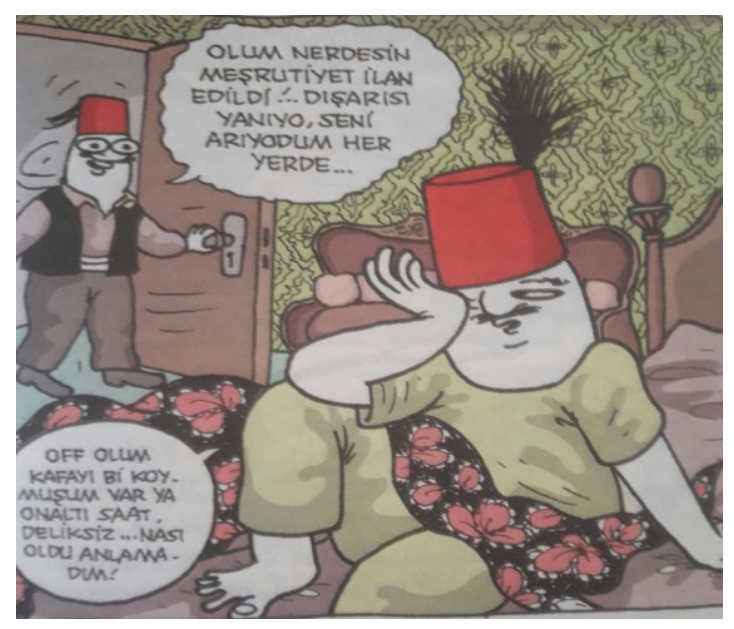

Karikatür 4: Cihan Ceylan, Uykusuz Dergisi, 9 Temmuz 2015, s. 12.

Gösteren: Uykudan yeni uyanmış fesli erkek, haber vermek üzere gelen bir başka fesli erkek, yatak, yorgan, kanepe ve kapı.

Gösterilen: Osmanlı döneminde insanların tembelliği ve ülke meselelerine kayıtsızlığı ima edilmektedir.

Yorum: Karikatürde uykusundan henüz uyanmış adamın kafasında fesle çizilmesi ve uyurken dahi kafasında fes bulunduğu şeklinde bir izlenim vermesi için fes püskülünün

\footnotetext{
${ }^{78}$ Bk. Galip Naşit, Destan, 12; Ali Zühtü \& Müçteba Selahattin, Tarih Utandl, 6; Samih Nafiz Tansu, Türk Inkılâp Tarihi ve Büyük Harpten Sonra Avrupa (Kenan Basımevi Klişe Fabrikası, 1938), 149; Yaşar Nabi, İkılap Çocuklarl, 12-14; Yaşar Nabi, Beş Devir (Ankara: Hakimiyet-i Milliye Matbaası, 1933), 7; Aker, Inkılâbımız Hakkında Köylüye Öğ̈̈tler, 1; Vasfi Mahir, Yaman (İstanbul: Devlet Matbaası, 1933), 44; Cevat Hakk1, Gazi’yi Dinlerken (Kırşehir: Vilayet Matbaası, 1933), 8-9; Sadri Etem, Bir Varmış Bir Yokmuş (İstanbul: Devlet Matbaas1, 1933), 4-8.
} 
dağınık resmedilmesi bu figürün öne çıkarılmaya çalışıldığının işaretidir. Gerek Meşrutiyet ifadesi ve gerekse fes gösterenleri ile Osmanlı temasının işlendiği açık bir şekilde gözlenmektedir. Oryantalist bakış açısını yansıtan ve fakat modernleşme döneminde Müslüman aydınlarda da görülen, gerileme ve çöküşün temel sebebini İslam'da ve o günkü din anlayışında arama eyleminin yöneldiği hedeflerden biri atıl, hareketsiz, vurdumduymaz, gözü ahirete dönük bir toplumsal yapı ve ilişkiler ağıdır. ${ }^{79}$ Gerek karikatürde yer alan gösterenlerin gerekse kurulan söylemlerin böyle bir anlayışı çağrıştırmakta, beslemekte ve yeniden üretmektedir. Aradaki fark ise modernleşme dönemi Müslüman aydınların hedefi Osmanlı ve İslam'ın ihya edilmesi ve tekrar güçlendirilmesi iken, karikatürle verilmek istenen mesaj Osmanlının olumsuzlanması olmaktadır. Kemalist dönemde oluşturulan yapay dil ile, müsebbibi padişahlar ve devlet olarak gösterilmekle birlikte, fesin ve Osmanlı döneminin atıllık, tembellik, vurdumduymazlık ile eşitlendiği söylenebilir. Bu minvalde karikatürde Meşrutiyet'in ilanını haber veren karakter, Osmanlı tarihindeki böylesi büyük bir olaya bir magazin olayı olarak yaklaşır şekilde, diğer karakter ise vurdumduymaz ve atıl bir şekilde resmedilmekte ve böylelikle Osmanlı dönemindeki halkın durumu gösterilmeye çalışılmaktadır.

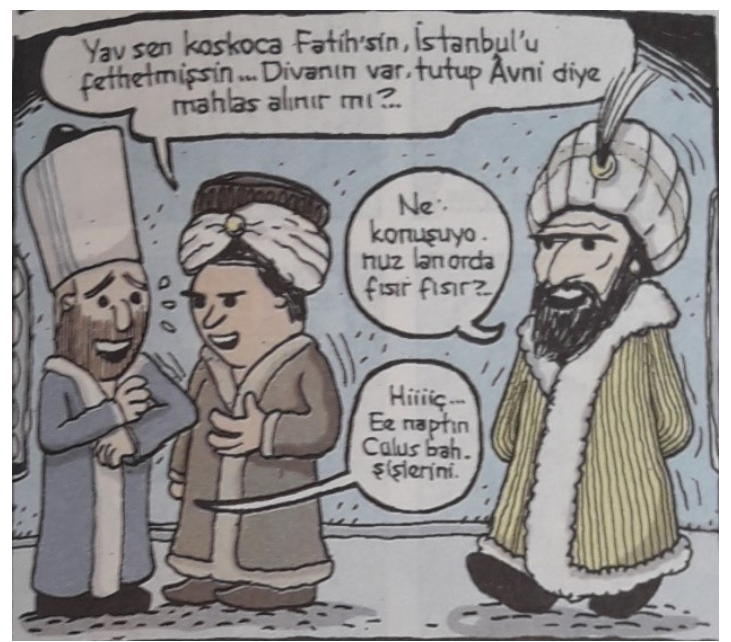

Karikatür 5: Furkan Özçoban, Uykusuz Dergisi, 9 Temmuz 2015, s. 14.

Gösteren: Fatih Sultan Mehmet ve farklı başlıklarda iki devlet görevlisi.

Gösterilen: Özellikle yükselme döneminden bir padişah olan Fatih Sultan Mehmet'in tedirginliği ve otoritesizliği gösterilmektedir.

\footnotetext{
79 İsmail Kara, Din ile Modernleşme Arasında Çağdaş Türk Düşüncesinin Meseleleri (İstanbul: Dergâh Yayınları, 2012), 35.
} 
Yorum: Karikatür, padişahın mahlasını aşağılama üzerine kurulmuştur. Oğuz Aral'ın Gırgır dergisinde oluşturduğu "Avanak Avni" tiplemesini de hatırlatan çizime dair sorulması gereken ilk soru "Avni isminin neden komik bulunduğu" olsa gerektir. Yeşilçam filmlerinde de sıkça rastlanıldığı üzere, Mürteza, Şaban (İnek Şaban), Ramazan, İsmail, Şemsi gibi dinî/geleneksel fonetiği güçlü erkek isimleri espri malzemesi olarak kullanılmaktadır. Furkan Özçoban dergideki bir başka çiziminde, Emre Kongar'1 telefon rehberinde "Muzaffer, Münir, Mükerrem" olarak verilen arkadaş isimlerine bakarken resmetmekte ve kendisine "yaşıtlarım arasında tek Emre benim. Yine farkımı ortaya koydum" cümlesini söyletmektedir. ${ }^{80}$ Osmanlı Devleti'nin gerek idarî gerekse fetihler anlamında yükselişte olduğu bir dönem padişahı olan Fatih Sultan Mehmet karikatürde elleri arkada bir vaziyette, ki bununla "kendini otoriter sanan padişah" mesajı verilmeye çalışllıyor görünmekte, maiyeti tarafından alaya alınırken resmedilmektedir. Otoritesi, gücü ve devlet idaresindeki başarısı üzerine kurulan bir tarih anlatımı, padişahın mahlası üzerinden mizaha konu edilmektedir denilebilir. Padişahın tahta geçmesi ile asker ve memurlara dağıtmış olduğu cülus bahşişinin Fatih Sultan Mehmet döneminde kanunlaştırıldı̆̆ bilinmektedir ve karikatürde bundan hareketle cülus işleniyor olsa gerektir. Güçlü devlet adamlığı ile ünlenen Osmanlı padişahlarından biri olan Fatih'in, sadrazam olduğu tahmin edilen, bir devlet adamının lakayt bir şekilde cülus bahşişi ile ilgili hesap sorarken resmedilmesi padişahın mezkûr ününü yıkma amacına yönelik olduğu söylenebilir. Kemalist literatür tarafından padişahlara dair kurulan "idaresiz padişah" söylemi karikatürden ayrıca takip edilebilmektedir. "Yardım eden" anlamına gelen Avni isminin mizaha konu edilmesi ve "çağ açıp çağ kapatan”, "dünya tarihinin akışını değiştiren” gibi metih ifadeleri ile anılan Fatih Sultan Mehmet'in resmediliş şekli, toplumun tamamı değilse de en azından bir kısmında rahatsızlık uyandıracaktır. Karikatürlerin hatırı sayılır bir kısmını politik olarak niteleyen Murat Belge' nin aşağıda yer verilecek olan şu ifadeleri esasında Uykusuz dergisinin Osmanlı karikatürlerine dair geçerli bir yorum olarak kabul edilebilir:

“Şu halde Lunaçarski'nin Çarlık Rusya'sından çıkardığı şu genelleme bize de fazla yabancı olmamalı. Lunaçarski mizahın bir türlüsünü bir çeşit başarısızlığa bağlıyor: Karşınızda "dost" sayamayacağınız bir güç var- büyük bir güç. Bu nedenle onu yenemiyorsunuz, bir karşılaşmaya girmekten de çekiniyorsunuz. Yani biraz çaresizsiniz. Bu durumda mizah imdadınıza yetişiyor. Yenemediğiniz, yok edemediğiniz, değiştiremediğiniz bu "gücü" gülünçleştiriyorsunuz. Bunu yapabiliyorsanız, ona karşı mücadeleye girdiniz demektir. Şu andaki acı, hınçlı

\footnotetext{
${ }^{80}$ Furkan Özçoban, Uykusuz Dergisi, 9 Ağustos 2018, 4
} 
gülüşünüz, bu mücadelenin sonunda kendinden emin, kaygısız bir kahkahaya dönüşebilir." 81

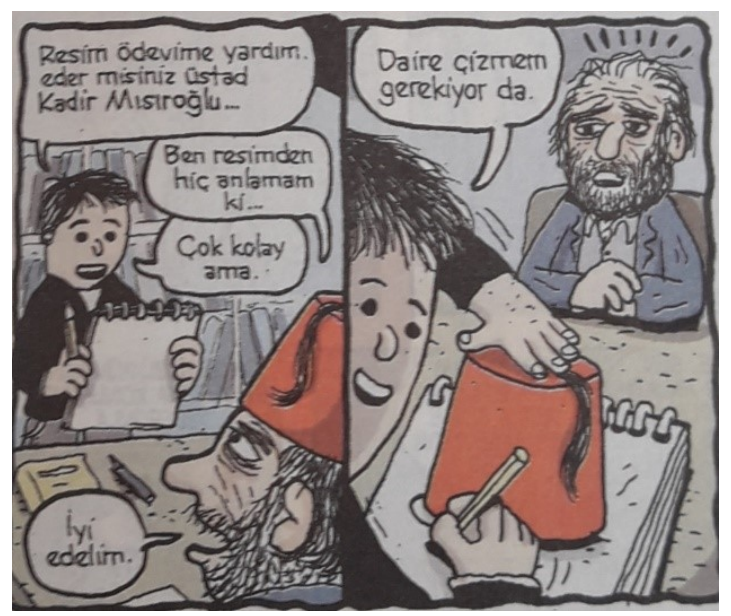

Karikatür 6: Furkan Özçoban, Uykusuz Dergisi, 9 Temmuz 2015, s. 14.

Gösteren: Kadir Mısırlığlu, ilkokul çağında küçük bir erkek çocuk, fes, masa, defter, kalem.

Gösterilen: Mısırlığlu kendisine çok büyük anlamlar yüklese de fesin insanlarda hiçbir karş1lı̆̆1 yoktur.

Yorum: Derginin de dahil edilebileceği kendini seküler olarak tanımlayan kesim tarafından "Atatürk düşmanı", “gerici” ve "karşı devrimci” gibi sıfatlarla anılan Kadir Mısıroğlu'nun kendisinin büyük bir anlam yükleyerek uzun süredir ısrarla takmış olduğu fes karikatürde konu edilmektedir. Mısıroğlu'nun Osmanlıya ve dine/İslam'a yaptığı vurguların göstereni olarak bilinen fes, çizer tarafından adeta basitleştirilmektedir. Oryantalizm tarafından Türk, Osmanlı ve Müslüman ile özdeşleştirilen fes bu haliyle, bu anlamıyla kabul görmüştür. Bu anlamda karikatür her ne kadar Mısıroğlu üzerinden ve yine Mısıroğlu'nu tenkit üzerinden işlese de fes göstereninin işaret ettiği gösterilen kısmı da nazar-ı dikkate alınmalıdır.

\footnotetext{
${ }^{81}$ Turgut Çeviker, Karikatürkiye: Karikatürlerle Cumhuriyet Tarihi (1923-2008) (İstanbul: NTV Yayınları, 2010), 1/33.
} 


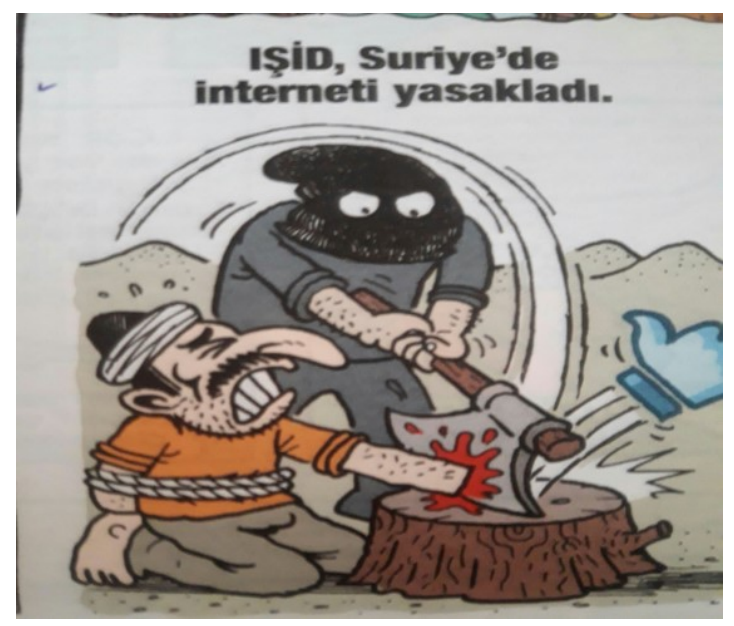

Karikatür 7: (Çizeri belli değil), Uykusuz Dergisi, 20 Ağustos 2015, s. 2.

Gösteren: Yüzü maskeli Işid militanı, bağlanmış bir şekilde eli kesilen sarıklı bir adam, kütük, balta ve "beğenme" anlamina gelen sosyal medya simgesi.

Gösterilen: İslam şeriatını benimsediğini iddia eden bir terör örgütünün sosyal medya yasağı getirmesi ve bu yasağı ihlal edenleri yine şeriata uygun şekilde cezalandırması işlenmektedir.

Yorum: Karikatürde Osmanlı vurgusu açık bir şekilde gözlenmese de din, İslam, şeriat, Osmanlı kavramları üzerinde yaşanılan topraklarda çağrışımsal olarak birbirini tamamlayan kavramlardır. Sarık göstereni hem bir coğrafya hem de bir dini vurgudur. Orta Doğu'nun ağırlıklı olarak Müslüman olması ve kılık kıyafet anlamında dini/İslami unsurların görünür olması karikatürün de şekillenmesinde etkili olmuştur. İslam şeriatında had cezaları arasında yer alan "el kesme" eylemi ve Işid terör örgütünün vahşeti karikatürde mezcolunarak verilmektedir. Hz. Peygamber'in hadisleri ve uygulamaları ile had cezalarının olabildiğince düşürülmeye çalışıldığı yaygın olarak bilinen bir husus iken karikatürde basit bir sosyal medya yasağı ile ilişkilendirilmesi yalnızca Işid eleştirisi değil, dinin/İslam'ın şiddet yanlısı olduğuna yönelik bilinçli bir şekilde oluşturulan algıyı da beslemektedir. Işid'in İslam devleti ve şeriatı vurgusunun kabul edildiğinin gözlendiği çizimin Müslüman toplumun dini hassasiyetini zedeleyecek bir şekilde dizayn edildiği görülmektedir. 


\section{2018 MAYIS-AĞUSTOS AYI}

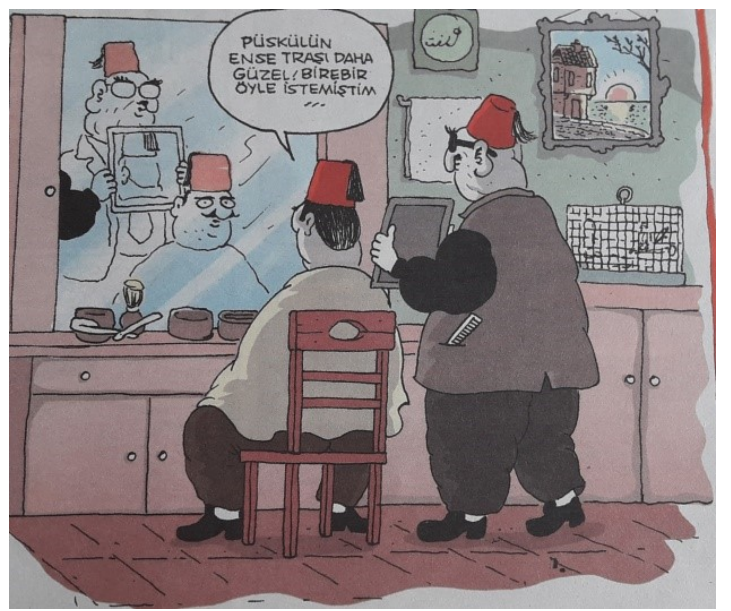

Karikatür 1: Cihan Ceylan, Uykusuz Dergisi, 3 Mayıs 2018, s. 12.

Gösteren: Birisi berber birisi müşteri olmak üzere, bol kıyafet, fes ve şalvar pantolon ile dikkat çeken iki adam, Arap harfleriyle yazılmış bir metnin yer aldığı tablo, Osmanlı dönemi bir evin de olduğu bir manzara tablosu, eski bir sandalye, tıraş malzemeleri, havlu ve bir berber dükkânı ortamı.

Gösterilen: Osmanlı dönemi bir berber dükkanında berber ve müşterisi arasında geçen bir diyalog ile fes ve özellikle fes püskülüne verilen önem gösterilmek istenmektedir.

Yorum: Fesin Osmanlı toplumundaki yaygınlığı, merkeziliği ve önemi işlenmeye çalışılmaktadır. Osmanlı döneminde bir berber ortamında fes püskülüne yapılan böylesi bir vurgu, fes püsküllerinin açık havada herhangi bir sebeple dağılması ve bu sebeple, ağırlığı Yahudi çocuklardan oluşan, "püskül tarayıcıları"nı akla getirmektedir. Karikatürde Osmanlı dönemi insanları çokça yer verildiği üzere, yine memnuniyetsiz, ikilemde ve mutsuz resmedilmektedir. Özellikle oryantalist eserlerin de katkısıyla Türk, Müslüman ve Osmanlı içerimlerinin üçü ile birden simgeleşen bir gösteren olarak fes, dergide sıkça kullanılmaktadır. Din/İslam ile birlikte Osmanlı kimliğini yansıtmada oldukça güçlü bir gösteren olan fes, yine aynı gerekçeyle Kemalist literatürde de merkezi bir konumda yer almaktadir. 


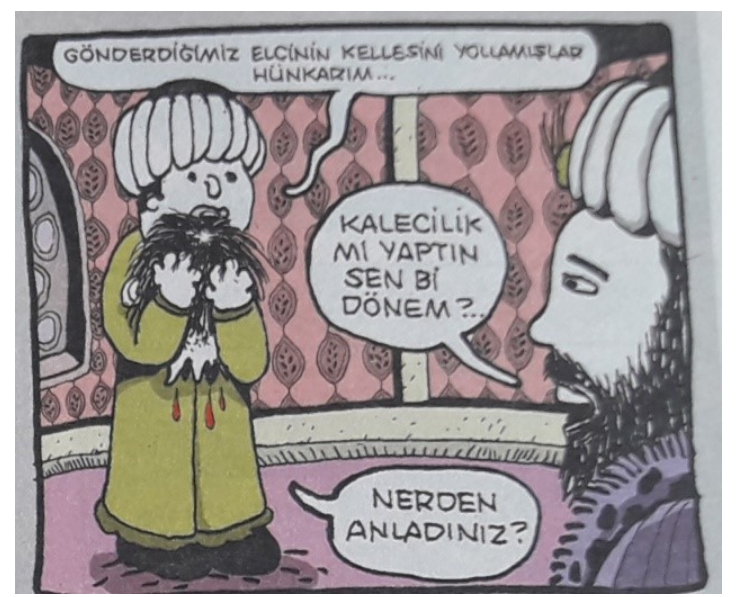

Karikatür 2: Furkan Özçoban, Uykusuz Dergisi, 31 Mayıs 2018, s. 14.

Gösteren: Padişah, padişahın hizmetinde bir görevli, kesik bir baş ve padişahın makamı olarak isimlendirilebilecek bir oda.

Gösterilen: Kanlar akan bir insan başının padişahta hiçbir etki yaratmamasıdır.

Yorum: Kucağında kan damlayan kesik bir insan başı olan korku içinde bir devlet görevlisi ve bunun karşısında oldukça soğuk kanlı ve espri yapan bir padişah resmedilmektedir. Çizimdeki ikinci tema da başarısızlık olarak tespit edilebilir. Karikatürde kan damlaları göstereni Osmanlı dönemine dair kurulan "zalim ve kan dökücü padişah", "kızıl maske"82 ve "sarayın bir kanara gibi kokması" 83 şeklindeki söylemleri akla getirmektedir.

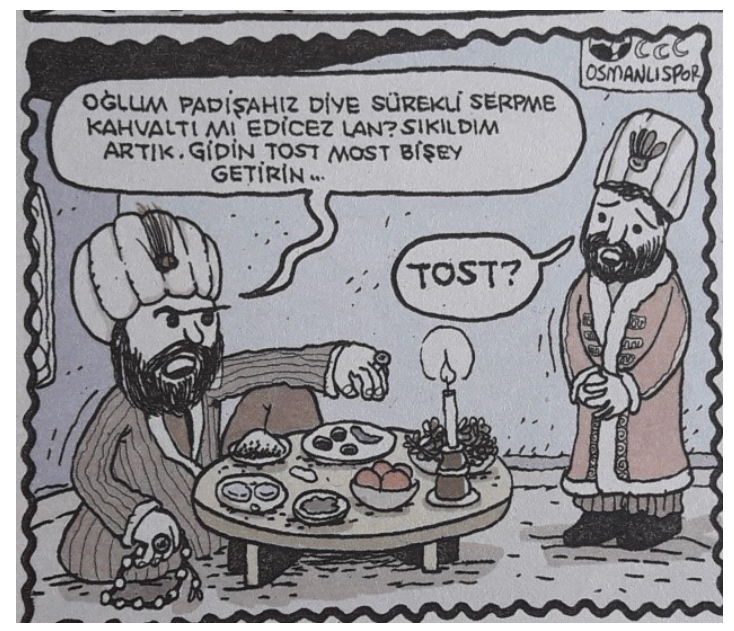

Karikatür 3: Furkan Özçoban, Uykusuz Dergisi, 26 Temmuz 2018, s. 4.

Gösteren: Padişah, padişahın hizmetinde bir görevli, tespih, iri bir yüzük, sofra ve mum ve duvarda Osmanlı Spor posteri.

\footnotetext{
${ }^{82}$ Yaşar Nabi, Inkılâp Çocuklarl, 149.

${ }^{83}$ Mahmut Esat Bozkurt, Atatürk İhtilâli, Ek: XVII (İstanbul Üniversitesi Yayınları, 1940), 407.
} 
Gösterilen: Mutsuz bir padişah, ondan korkan, çekinen ve imkân olmasa dahi her türlü isteğini yerine getirmeye çalışan bir düzen/devlet düzeni resmedilmeye çalışılmaktadır.

Yorum: Osmanlı padişahlarının konu edildiği karikatürlerde sıkça rastlanan Osmanlı dönemi ve bugünün mezcedilerek verilmesidir. "Osmanlı Spor posteri" ve "tost" gösterenleri ile padişah günümüze taşınmıştır. Diğer bir ifadeyle, güçlü tarihî bir şahsiyet kendi döneminden koparılarak resmedilmektedir. Dönemi dışında çizilme mizahı yakalayabilme adına başvurulabilecek bir yöntem olmakla birlikte, dergide padişahların bu şekilde çizilmeleri ile verilen mesaj, ihtiyatlı bir şekilde ifade edilecek olunursa, ekseriyetle mutsuzluk ve memnuniyetsizlik olmaktadır. Buna ek olarak ifade edilmesi gereken padişahların müspet mesajlar içeren hiçbir karikatürde yer almamalarıdır. Tüm bunlar, derginin Osmanlı göstergesini işlemiş olduğu karikatürleriyle, yerleşmiş bir algı olarak "güçlü padişah" algısına yönelmiş olduklarına yönelik bir kanaati meydana getirmektedir. Karikatürde padişahın gücü, bağdaş kurmuş bir halde oturuşu ve elindeki tespihi ile gösterilmeye çalışılmış olmakla birlikte yine resmî ideoloji ile kurulan "padişahların ehli keyif oldukların" yönelik söylem beslenmiştir. Gücün bu şekilde gösterilmesi, herhangi bir devlet adamında olan güçten ziyade müstebit bir yönetici algısına yapılan vurgu olarak okunabilir. Bununla birlikte yine tedirginlik, ikilem ve mutsuzluk karikatürde merkezi temalar olarak bulunmaktadır. Padişahın karşısında el pençe bir halde ve onun imkânsız isteği karşısında korku içerisinde ne yapacağını bilemez halde duran bir görevli çizimi ise müstebit ve ehli keyif padişah algısının altını çizen bir gösterendir.

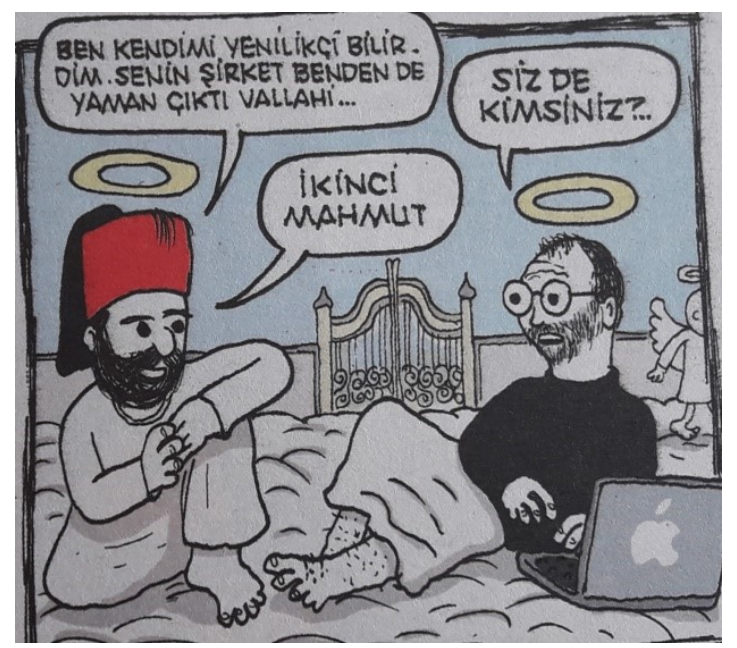

Karikatür 4: Furkan Özçoban, Uykusuz Dergisi, 16 Ağustos 2018, s. 4.

Gösteren: II. Mahmut, Steve Jobs, gösterişli bir kapı, Apple marka bir bilgisayar ve melek kanatlı bir çocuk. 
Gösterilen: Osmanlı tarihinde "yenilikçi" olarak kabul edilen bir padişahın esasında çok da önemli bir icraatının olmaması ve bu sebeple "parlak zekâ" ve "dahi" olarak bilinen ve dünyaca kabul edilen Steve Jobs tarafından tanınmamasıdır.

Yorum: Karikatürde II. Mahmut ve Steve Jobs “diğer dünya" olarak isimlendirilebilecek bir alemde yan yana resmedilmiştir. Zemindeki bulutsu çizim, melek çocuk ve iki figürün kafalarının üzerindeki daireler ile dünya dışında bir mekân tasvir edilmeye çalışılmıştır. Zekâsı ve buluşu ile herkes tarafından takdir gören bir figür olarak Jobs, Osmanlı tarihinde yenilikçi olarak bilinen önemli bir simayı tanımamaktadır. II. Mahmut döneminde, haklarında olumlu veya olumsuz değerlendirmelerin yapıldığı birçok yenilik/icraat yapılmıştır. Bununla birlikte çoğunlukla müspet yorumlara muhatap olan insan hakları, özgürlükler ve eğitim alanında da birtakım yenilikler/iyileştirmeler yapılmıştır. Otuz sene süren ve Osmanlının en önemli dönemi olarak okunan bir dönemin padişahı olarak II. Mahmut, Jobs ile kıyaslanırken, fese sabitlenmiş, aynı zamanda bu durum basitleştirilmiştir. Asıl yenilikçi olarak Jobs'a işaret edilmiş, II. Mahmut'un tanınmayışı ile padişahın icraatlarının yanında "Büyük Osmanlı Devleti" algısına da pejoratif bir dokundurma söz konusudur denilebilir.

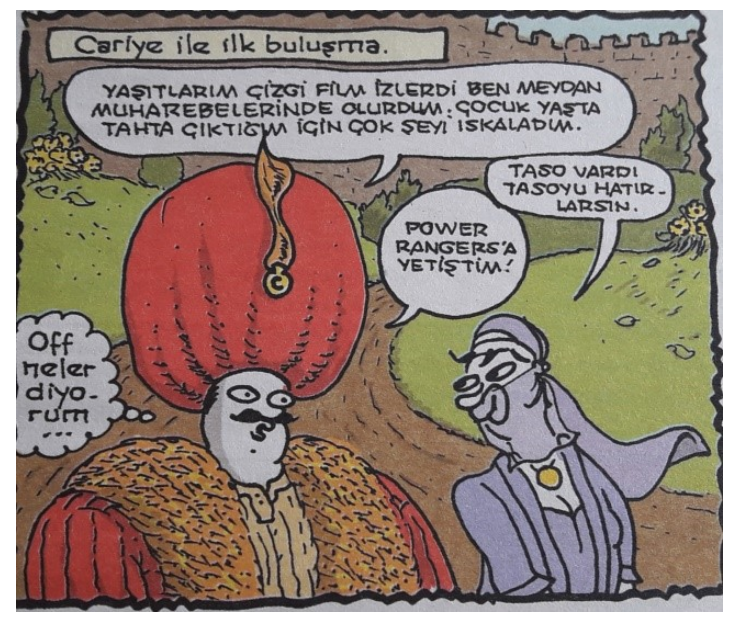

Karikatür 5: Cihan Ceylan, Uykusuz Dergisi, 30 Ağustos 2018, s. 12.

Gösteren: Padişah, cariye ve sarayın bahçesi.

Gösterilen: Padişahın cariye karşısında heyecanlanmasıdır.

Yorum: Gösterişli kaftanı ve oldukça büyük başlığı ile "koca padişah" imajı oluşturulmaya çalışılmakla birlikte cariye karşısında heyecanlanan, aciz ve komik bir duruma düşen bir profil de çizilmiştir. Yine kendi dönemi dişındaki bir kurgunun içinde çizilen padişah, söylemlerinden anlaşıldığı üzere, yine mutsuz, özneleşme süreci hakkında şikayetçi, tedirgin 
ve bir ikilem üzeredir. Cariye karşısında çizilen padişah tasviri, Kemalist literatürde geçen "saraya güzel kız altın para yağdırmaktan usandık", ${ }^{44}$ "haremağalarına akıl danışan padişah" 85 ve "Rum, Ermeni ve Çerkes kadınlarının ellerinde oyuncak olmuş padişah" 86 ifadelerini hatırlatmaktadır.

\section{DEĞERLENDİRME VE SONUÇ YERINNE}

Çalışmada modern, seküler, Kemalist çizgi üzerinde konumlandırılabilecek olan Uykusuz dergisi, 2015 yılı Mayıs-Ağustos ve 2018 yılı Mayıs-Ağustos olmak üzere toplam otuz iki sayı boyunca Osmanlı temsili üzerinden taranmış ve iki dönem arasında kıyaslama yapılmaya çalışılmıştır. Yapılan kıyasa dair söylenilmesi gereken ilk husus çizgide ve gösterilenler hususunda bir farklılığın bulunmadığıdır. Bununla birlikte çalışmada kapsam dışına alınan siyasi içerikli ve pornografik mahiyetteki karikatürler akılda tutularak söylenecek olursa, 2018 sayılarında Osmanlı toplumsal yaşamına dair karikatürlerin sayısının arttığı ve fes göstereninin altının çizildiği belirtilmelidir. Karikatürlerdeki gösteren ve gösterilen ilişkisi Saussure'ün göstergebilim yaklaşımı üzerinden okunmaya çalışılmıştır. Gösterge bütününü oluşturan gösteren ve gösterilen arasındaki nedensizlik ilkesi ve bu noktada kurulan bağlantıdaki kültür vurgusu, Kemalist ideoloji/Cumhuriyet ideolojisi vurgusu ile desteklenerek sunulmuştur.

Dergi çizimlerinden hareketle Osmanlı temsili gösterenleri sarık, cübbe, fes, sakal, tespih, takke, şalvar şeklinde tespit edilmiştir. Gösterilenler ise "Şark, din/İslam, tarih, İslam tarihi, gelenek, gericilik, gelişmemişlik, başarısızlık, tedirginlik, otoritesizlik, kadın ve kan" şeklinde tespit edilebilir. Saussurecü anlamda Osmanlı göstergesinin bu iki bileşeni yani gösteren ve gösterileni arasında nedensizlik ilişkisi bulunmaktadır. Söz gelimi tespih göstereninin Osmanlı ile hiçbir içsel bağı bulunmamaktadır. Saussure'ün göstergenin tarihsel etkilere açık oluşu, gösteren ve gösterilen arasındaki bağın zamanla bozulması/değişmesi ilkesi çalışmada zikredilen gösterenlerin Osmanlıya işaret edişinin bir açıklaması olarak kabul edilebilir. Gösteren ve gösterilen arasındaki kurulan bağ ve anlamlandırma sürecinde kültürel buyruğun önemi bu düşüncede kabul edilen temel ilkeler arasındadır. Saussurecü düşüncede değişim dil dizgesinde değil, sözde gerçekleşir. Söz dil yetisinin bireysel edimi barındıran kısmıdır, burada insan iradesi söz konusudur. Bu noktada bu eşleşimi mümkün kılan bir kullanım ile bu gösterge toplumda yaygınlık kazanır, yerleşir ve nihayetinde dil dizgesini etkiler, kanunlaşır. Osmanlı göstergesinin dil dizgesini etkileyecek boyuta ulaşıp ulaşmadığı çalışmada soru olarak bırakılmıştır. İçerisinde bulunulan kültürel harita özelinde anlam kazanan bu eşleşim anlıksal ve çağrışımsaldır.

\footnotetext{
${ }^{84}$ Aka Gündüz, Yarım Osman (Ankara: Hakimiyet-i Milliye Matbaası, 1933), 8.

${ }^{85}$ Fuat Hulusi, Yllların Dili, 42.

${ }^{86}$ Cevat Hakkı, Gaziyi Dinlerken, 8.
} 
Düşünürün "gösterenin çizgiselliği/yayılım göstermesi" ilkesi ise bir gösteren kümesi oluşmasına imkân sağlamakta, fesin, sarık, tespih ve diğer gösterenlerle kurduğu paradigmatik ilişkiyi açılamaya imkân tanımaktadır. Bir örnek üzerinden gidilecek olunursa "Şeriate göre hırsızlığın cezası el kesmedir" cümlesinde, dilsel öğelerin dizilişi bakımından, dizimsel (sentegmatik) ilişki söz konusu iken, şeriat ifadesinin içinde bulunulan coğrafyada, Osmanlı, İslam, İslam tarihi, gelenek, Şark, gericilik kavramlarını çağrıştırması bakımından da çağrışımsal (paradigmatik) ilişki bulunmaktadır. Saussure'ün eserinde çok az yer vermiş olduğu "yapay dil" mevzu ise Osmanlı göstergesi özelinde anlam kazanmaktadır. Gerek bu dilin oluşması gerekse Osmanlı göstergesindeki gösteren ve gösterilen ilişkisine yön veren bir tarih diliminden bahsedilebilir. Çalışmada bu anlamda Cumhuriyet ideolojisine ve 1930'lu y1llara işaret edilmekte ve göstergenin olduğu yerde ideoloji vardır ifadesinin altı çizilmektedir.

Göstergeler kullanılarak ideolojiye can verilmekte ve yaşatılmaktadır. Bu noktada çalışmada karikatürlerdeki Osmanlı çizimlerini mümkün kılan Kemalist ideolojiye başvurulmuş ve aralarındaki ilişki tespit edilmeye çalışılmıştır. 1930'lu yıllarda kaleme alınan bir dizi Kemalist literatür tarafından kurulan Osmanlının, dergi karikatürlerinde de muhafaza edildiği gözlenmiş ve aralarında devamlılık tarzında bir ilişki tespit edilmiştir. Osmanlı padişahları dergi sayıları boyunca şişman, iri tespihler, gösterişli kıyafetler ile ve yemek yerken, otururken veya bir kadın ile resmedilmişlerdir. Sefere giden, savaş meydanında, önemli bir iş üzerinde veya çalışan bir padişah çizimine dergide rastlanmamaktadır. Padişahlar karikatürlerde ağırlıklı olarak kendi zamanları dışında resmedilmiş ve bu şekilde mizah yakalanmaya çalışılmış olmakla birlikte, önemli bir diğer husus da onlara oluşturulan psikolojik profil olsa gerektir. Yer yer Osmanlı devlet geleneğine de dokundurmaların yer aldığı karikatürlerde, padişahlar özneleşme süreçlerinden şikayetçi, mutsuz ve tedirgin çizilmişlerdir. Osmanlı'ya dair öne çıkarılan en önemli unsur padişah tiplemeleri ise bir diğeri festir. Ağırlıklı olarak toplumsal yaşamın resmedilmeye çalışıldığı karikatürlerde kullanılan fes göstereninin, gösterileni genel olarak atıllık, tembellik, mutsuzluk ve depresyon olarak tespit edilebilir. Osmanlı dönemi insan tiplemelerinin hepsinin, özellikle fes göstereni ile çizilen erkek tiplemelerinin şişman, mutsuz ve tembel çizilmeleri de dikkat çekilmesi gereken bir diğer husustur.

Türk toplumunun büyük bir kısmında önemli ve güçlü bir karşılığı bulunan Osmanlı göstergesi ile mizah yoluyla mücadeleye girilmiş ve Belge'nin ifadesiyle “yok edilemeyen güç gülünçleştirilmiştir" denilebilir. Osmanlı göstergesinde gösterilen kısmına dahil olan Şark, din/İslam, gelenek, gericilik, gelişmemişlik, başarısızlık, otoritesizlik ve kan" ise mücadelenin niteliğini gösteren tamamlayıcı unsurlardır. Bu noktada mizah ile Osmanlı meşruiyetinin yıkılmaya çalışıldığı söylenebilir. Saussure'ün dilin tarihsel etki altında 
olduğu düşüncesinden hareketle dergideki Osmanlı göstergelerini mümkün kılan tarihsel bir etki söz konusu olduğu söylenebilir. Gösterenin işaret ettiği gösterilen, Türkiye'de Osmanlı sempatisi olan kesimde de gerçekleşmektedir. Gösteren ve gösterilen arasında kurulan nedensiz bağ ve sonucunda gerçekleşecek mizah ise derginin hitap ettiği kesimde makes bulurken, karikatürde yer alan gösterenler ve kurulan söylemler Osmanlı hassasiyeti olan insanlar tarafında rahatsızlık uyandıracaktır. Yer verilmesi gereken bir diğer husus ise, çalışma kapsamında taranan otuz iki sayı boyunca tarihsel figürleri konu edinen karikatürlerin yalnızca Osmanlı dönemine ait olmasıdır. Söz gelimi tek parti dönemine ait hiçbir siyasi ve tarihsel figür olumlu veya olumsuz hiçbir şekilde işlenmemiştir ve bu devam eden Cumhuriyet tarihi için de aynı şekildedir. Buna mukabil Osmanlıyı konu alan karikatürlerin sayısı oldukça fazladır. Kemalizme atfedilen kutsiyet ${ }^{87}$, onun, olumlu dahi olsa, mizaha konu edilmesini engelliyor olsa gerektir. Söylenilmek istenen Osmanlı göstergesinin işleniş şekillerinin veya haricindeki dönem veya isimlerin işlenmemesinin ideolojik bir tercihten ileri geldiğidir. Saussurecü yaklaşımda bir göstergenin olmasının yanında olmaması da aynı derecede önemlidir.

Çalışma vesilesiyle altı çizilmek istenen önemli bir diğer husus ise tarih-karikatür ilişkisi, diğer bir ifadeyle tarihi görsel malzeme üzerinden yeniden okumaya yönelik çalışmaların azlığı ve hatta yokluğudur. Dönemin sosyolojisine görsel malzeme üzerinden yaklaşan çalışmalara ihtiyaç duyulmakla birlikte, özelleştirilecek olunursa günümüz medya organlarının Osmanlıyı gerek siyasi gerekse toplumsal anlamda, nasıl işlediği ile ilgili literatür oldukça eksik olduğu söylenebilir.

\section{KAYNAKÇA}

Aker, Cavit. İnkılâbımız Hakkında Köylüye Öğ̈̈tler. Muğla: Halk Basımevi, 1936.

Akman, Eyüp Hamdi. Türk Devrimi ve Devrimciliği. İzmir: Meşher Basımevi, 1936.

Althusser, Louis. İdeoloji ve Devletin İdeolojik Aygıtları. çev. Alp Tümertekin. İstanbul: İthaki Yayınları, 2014.

Barthes, Roland. Elements of Semiology. çev. Annette Lavers \& Colin Smith. New York: Hill and Wang Press, 1977.

Barthes, Roland. Göstergebilimsel Serüven. çev. Mehmet Rıfat \& Sema Rıfat. İstanbul: Kaf Yayıncilık, 1985.

\footnotetext{
${ }^{87}$ Kemalizm'in kudsiyetine ilişkin bk. Halit Fahri, On Yılın Destanı (Ankara: Hâkimiyet-i Milliye Matbaası, 1933), 23; Etem İzzet, On Yılın Romanı (İstanbul: Devlet Matbaas1, 1933), 59; Şaziye Berin, Baybiçe, 24; Cevat Hakkı, Gazi'yi Dinlerken, 49; Saffet Engin, Kemalizm Inkllabının Prensipleri, 2/79.
} 
Berin, Şaziye. Baybiçe. İstanbul: Devlet Matbaası, 1933.

Cahit, Burhan. Mudanya, Lozan, Ankara. İstanbul, 1933.

Ceylan, Cihan. Uykusuz Dergisi 22 (2015), 12.

Ceylan, Cihan. Uykusuz Dergisi 18 (2018), 12.

Ceylan, Cihan. Uykusuz Dergisi 35 (2018), 12.

Coward, Rosalind \& John Ellis. Dil ve Maddecilik. çev. Esen Tarım. İstanbul: İletişim Yayınları, 1985.

Culler, Jonathan. Saussure. çev. Nihal Akbulut. İstanbul: Afa Yayınları, 1985.

Çeviker, Turgut. Karikatürkiye: Karikatürlerle Türkiye Cumhuriyeti (1923-2008). 1 Cilt. İstanbul: NTV Yayınları, 2010.

Çiğdem, Ahmet. "Batılılaşma, Modernite ve Modernizasyon”. Modern Türkiye'de Siyasi Düşünce: Modernleşme ve Batıcılık. ed. Tanıl Bora, Murat Gültekingil. 3/68-81. İstanbul: İletişim Yayınları, 4. Basım, 2007.

Demirhan, Nezahat. Cumhuriyetin Onuncu Yılının Türk İnkılâp Tarihinde Yeri ve Önemi. Ankara: Atatürk Kültür, Dil ve Tarih Yüksek Kurumu, 1999.

Dilek, İltem. Uykusuz Dergisi 25 (2015), 7.

Dilek, İltem. Uykusuz Dergisi 27 (2015), 7.

Engin, Saffet. Kemalizm İnkılâbının Prensipleri. 2 Cilt. İstanbul: Cumhuriyet Matbaası, 1938.

Erkman, Fatma. Göstergebilime Giriş. İstanbul: Alan Yayınları, 1987.

Erol, Pelin Önder. "Bir Toplumsal Göstergebilim Alanı Olarak Dil”, Uluslararası Sosyal Araştırmalar Dergisi 7/31 (2014), 207-214.

Etem, Sadri. Türk İnkılâbının Karakterleri. İstanbul: Devlet Matbaası, 1933.

Etem, Sadri. Bir Varmış Bir Yokmuş. İstanbul: Devlet Matbaası, 1933.

Fahri, Halit. On Yılın Destanı. Ankara: Hâkimiyet-i Milliye Matbaası, 1933.

Fiske, John. İletişim Çalışmalarına Giriş. çev. Süleyman İrvan. Ankara: Ark Yayıncılık, 1990.

Gottdiener, Mark. Postmodern Göstergeler, Maddi Kültür ve Postmodern Yaşam Biçimleri. çev. Erdal Cengiz- Hakan Gür- Arhan Nur. Ankara: İmge Kitabevi, 2005.

Guiraud, Pierre. Göstergebilim. çev. Mehmet Yalçın. Sivas: M. Y. Özel Yayım, 1990. 
Hakkı, Cevat. Gazi'yi Dinlerken. Kırşehir: Vilâyet Matbaası, 1933.

Hodge, Robert, Gunther Kress. Social Semiotics. Ithaca: Cornell University, 1988.

Hulusi, Fuat. Yillarm Dili. İstanbul: Devlet Matbaası, 1933.

İpek, Selin. "Padişah Portreleri Seksiyonu”. Topkapı Sarayı'nı Anlatmak. ed. Ali Satan, Salim Aydın, Selim İpek. 340-347. Ankara: Kültür ve Turizm Bakanlığı, 2018.

İzzet, Etem. On Yılın Romanı. İstanbul: Devlet Matbaası, 1933.

Kara, İsmail. Din ile Modernleşme Arasında Çă̆daş Türk Düşüncesinin Meseleleri. İstanbul: Dergâh Yayınları, 3. Basım, 2012.

Kara, Seyfullah. "Millî Tarih Anlayışının Romantik Devri: Cumhuriyetin İlk Yılları". Atatürk Üniversitesi Türkiyat Araştırmaları Enstitüsü Dergisi 11/13 (2004), 319-334.

Koçak, Orhan. “1920'lerden 1970'lere Kültür Politikaları”. Modern Türkiye'de Siyasi Düşünce: Kemalizm. ed. Tanıl Bora, Murat Gültekingil. 2/370-382. İstanbul: İletişim Yayınları, 6. Basim, 2009.

Maarif Vekaleti. Osmanlı Imparatorluğu'ndan Türkiye Cumhuriyeti'ne Nasıldı? Nasıl Oldu?. 10. İstanbul: Devlet Matbaası, 1933.

Mahir, Vasfi. 10 İnkılâp. İstanbul: Ankara Matbaası, 1933.

Mahir, Vasfi. Yaman. İstanbul: Devlet Matbaası, 1933.

Muzaffer, Mediha. İnkılâbın Ruhu. İstanbul: Devlet Matbaası, 1933.

Nabi, Yaşar. Beş Devir. Ankara: Hakimiyet-i Milliye Matbaası, 1933.

Naşit, Galip. Destan. İstanbul: Devlet Matbaası, 1933.

Nedim, Vedat. 29 Birinci Teşrin. Ankara: Köy Hocası Matbaası, 1933.

Nimetullah, Halil. Halkçılık ve Cumhuriyet ve Türk Halkçılığı ve Cumhuriyeti. İstanbul: Orhaniye Matbaası, 1930.

Nüzhet, Selim. "Cumhuriyetin Onuncu Yıldönümünde Yapılan Neşriyat". Ülkü Halkevleri Mecmuası 2/12 (1934), 443-455.

Oktay, Ahmet. Popüler Kültürden TV Sömürgesine. İstanbul: İthaki Yayınları, 2009.

Onart, Adnan. “Değişik Yönleriyle Yapısalcılık ve "Yapı” Kavramı”. Türk Dili Dergisi 262 (1973), 231-260.

Öğüt, Zehra. İnkılâp Kitaplarında Din: 1930'lu Yıllar. İstanbul: Yazıgen Yayınları, 2018.

Özçoban, Furkan. Uykusuz Dergisi 28 (2015), 14. 
Özçoban, Furkan. Uykusuz Dergisi 28 (2015), 14.

Özçoban, Furkan. Uykusuz Dergisi 22 (2018), 14.

Özçoban, Furkan. Uykusuz Dergisi 30 (2018), 4.

Özçoban, Furkan. Uykusuz Dergisi 33 (2018), 4.

Özçoban, Furkan. Uykusuz Dergisi 32 (2018), 4

Parla, Taha. "Kemalizm Türk Aydınlanması mı?", Modern Türkiye'de Siyasi Düşünce: Kemalizm, ed. Tanıl Bora, Murat Gültekingil. 2/313-316. İstanbul: İletişim Yayınları, 6. Basım, 2009.

Rıfat, Mehmet. Göstergebilimin ABC'si. İstanbul: Simavi Yayınları, 1992.

Saussure, Ferdinand De. Genel Dilbilim Dersleri. çev. Berke Vardar. I-II Cilt. Ankara: Türk Dil Kurumu Yayınları, 1976.

Seyfi, Ali Rıza. Gazi ve İnkılâp. İstanbul: Sinan Matbaası ve Kütüphanesi, 1933.

Şahbaz, Fatih. "Kemalizm ve Seküler Fundamentalizm". Medeniyet Araştırmaları Dergisi 4/1 (2019), 1-17.

Şimşek, Ahmet \& Satan, Ali. Milli Tarihin İnşası. İstanbul: Tarihçi Kitabevi, 2011.

Tansu, Samih Nafiz. Türk İnkılâp Tarihi ve Büyük Harpten Sonra Avrupa. Kenan Basımevi ve Klişe Fabrikası, 1938.

Tarih IV. İstanbul: Devlet Matbaası, 1931.

Tarih III. İstanbul: Devlet Matbaası, 1932.

Türk Tarihinin Ana Hatları. İstanbul: Devlet Matbaası, 1930.

Tahsin, Suat. Türkiye Cumhuriyeti Devleti ve Bânisi Gazi Mustafa Kemal. İstanbul: Akşam Matbaası, 1933.

Uykusuz Dergisi 34 (2015), 2.

Uzun, Hakan. “Tek Parti Döneminde Yapılan Cumhuriyet Halk Partisi Kongreleri Temelinde Değişmez Genel Başkanlık, Kemalizm ve Milli Şef Kavramları". Çağdaş Türkiye Tarihi Araştırmaları Dergisi IX/20-21 (2010), 233-271.

Vardar, Berke. Genel Dilbilim Dersleri. İstanbul: Multilungual Yayınları, 1998.

Zühtü, Ali \& Müşteba Selahattin. Tarih Utandı. İstanbul: Devlet Matbaası, 1933. 